\title{
UK monitoring and deposition of tephra from the May 2011 eruption of Grímsvötn, Iceland
}

\author{
John Alexander Stevenson ${ }^{*}$, Susan C Loughlin², Anna Font ${ }^{3}$, Gary W Fuller ${ }^{3}$, Alison MacLeod ${ }^{4}$, \\ lan W Oliver ${ }^{5}$, Ben Jackson ${ }^{6}$, Claire J Horwell ${ }^{7}$, Thor Thordarson ${ }^{1,9}$ and lan Dawson ${ }^{8}$
}

\begin{abstract}
Mapping the transport and deposition of tephra is important for the assessment of an eruption's impact on health, transport, vegetation and infrastructure, but it is challenging at large distances from a volcano $(>1000 \mathrm{~km})$, where it may not be visible to the naked eye. Here we describe a range of methods used to quantify tephra deposition and impact on air quality during the 21-28 May 2011 explosive basaltic eruption of Grímsvötn volcano, Iceland. Tephra was detected in the UK with tape-on-paper samples, rainwater samples, rainwater chemistry analysis, pollen slides and air quality measurements. Combined results show that deposition was mainly in Scotland, on 23-25 May. Deposition was patchy, with adjacent locations recording different results. Tape-on-paper samples, collected by volunteer citizen scientists, and giving excellent coverage across the UK, showed deposition at latitudes $>55^{\circ} \mathrm{N}$, mainly on 24 May. Rainwater samples contained ash grains mostly 20-30 $\mu \mathrm{m}$ long (maximum recorded grainsize $80 \mu \mathrm{m}$ ) with loadings of up to 116 grains $\mathrm{cm}^{-2}$. Analysis of rainwater chemistry showed high concentrations of dissolved Fe and Al in samples from N Scotland on 24-27 May. Pollen slides recorded small glass shards (3-4 $\mu \mathrm{m}$ long) deposited during rainfall on 24-25 May and again on 27 May. Air quality monitoring detected increased particulate matter concentrations in many parts of the country. An hourly concentration of particles $<10 \mu \mathrm{m}$ in diameter $\left(\mathrm{PM}_{10}\right)$ of $\sim 413$ $\mu \mathrm{g} \mathrm{m}^{-3}$, was measured in Aberdeen at 02:00hrs on 24 May 2011. Significant peaks of non-anthropogenic PM, which is most likely to have a volcanic origin, could be tracked as far south as the English Midlands ( $>53^{\circ} \mathrm{N}$ ) on 24 May but no negative effects on health were reported. Although the eruption column reached altitudes of $20 \mathrm{~km}$ above sea level, air mass trajectories suggest that only tephra from the lowest $4 \mathrm{~km}$ above sea level of the eruption plume was transported to the UK. This demonstrates that even low plumes could deliver tephra to the UK and suggests that the relative lack of basaltic tephra in the tephrochronological record is not due to transport processes.
\end{abstract}

Keywords: Tephrochronology; Volcanic ash; $\mathrm{PM}_{10} ; \mathrm{PM}_{2.5}$; Citizen science

\section{Introduction}

Explosive eruptions generate tephra that can be carried far downwind from the volcano. The effects of tephra deposition include damage to infrastructure (Wilson et al. 2012), acidification (or fertilisation) of soils and lakes (Grattan 2005), poisoning of livestock (Cronin et al. 1998), and increased respiratory mortality (Newnham et al. 2010). While these effects are felt much less acutely at greater distances, even small effects can only be understood in the context of information on the timing,

\footnotetext{
*Correspondence: johnalexanderstevenson@yahoo.co.uk

1 School of GeoSciences, The University of Edinburgh, Grant Institute, West Mains Road, Edinburgh, EH9 3JW, UK

Full list of author information is available at the end of the article
}

location and character of tephra deposition. Quantitative data on very distal $(>1000 \mathrm{~km})$ tephra deposition during modern eruptions are few, but they are necessary for the validation of dispersion models (Witham et al. 2007) and to understand the formation of cryptotephra layers, which are an important dating tool (Lawson et al. 2012). The aim of this study was to map the deposition and impact of a contemporary explosive eruption at large distances from the volcano. A secondary aim was to involve citizen scientists to improve public understanding of volcanic eruptions and to build preparedness for future events.

Iceland's volcanoes are located over $850 \mathrm{~km}$ from the UK and over $1000 \mathrm{~km}$ from Scandinavia, yet there are many examples of deposition of Icelandic ash in Europe. The 2010 Eyjafjallajökull eruption deposited volcanic ash

\section{是 Springer}

(c) 2013 Stevenson et al : licensee Springer. This is an Open Access article distributed under the terms of the Creative Commons Attribution License (http://creativecommons.org/licenses/by/2.0), which permits unrestricted use, distribution, and reproduction in any medium, provided the original work is properly cited. 
grains $20-100 \mu m$ in length in the Faroe Islands, Norway and the UK, and air filters collected smaller grains (2$6 \mu \mathrm{m})$ as far away as Budapest, Hungary, $3000 \mathrm{~km}$ from the vent (Stevenson et al. 2012). Larger, recent, historical eruptions that deposited significant tephra in Europe include the 1947 Hekla and 1875 Askja eruptions (Thorarinsson 1981). In a review of tephras found in the Faroe Islands, Scandinavia, the United Kingdom and Germany, Swindles et al. (2011) report 19 tephra layers across northern Europe produced in the last 1000 years. For comparison, mapping and dating of deposits in Iceland, combined with analysis of written records, finds 124 explosive eruptions since the country was settled circa 870 A.D. (Thordarson and Larsen 2007), while climatological studies suggest that the wind is likely to transport tephra to the UK around one third of the time (Leadbetter and Hort 2011). Therefore given the problems of patchy deposition (e.g. Stevenson et al. 2012; Wastegård and Davies 2009) and of the under-representation of basaltic tephra relative to its eruption frequency (Thordarson and Larsen 2007), the tephrochronological record provides only a minimum estimate of the frequency of Icelandic tephra deposition in Europe.

The May 2011 Grímsvötn eruption was shorter-lived but more powerful than the 2010 Eyjafjallajökull eruption, and coincided with the passage of a series of low pressure systems to the south of Iceland that caused rainfall and rapid variations in wind direction. Here we present results of sampling and analysis of volcanic ash from across the United Kingdom. We expand the range of methods used during the 2010 Eyjafjallajökull eruption to include data from a nationwide public sampling campaign, pollen sampling, rainwater chemistry and estimates of non-anthropogenic airborne particle concentrations in air quality monitoring data. The results demonstrate that tephra deposition can be mapped at large distances from Iceland, but that uncertainties can be high where concentrations are low.

\section{Background}

\section{Terminology}

The term 'tephra' refers to all sizes of ejecta produced during explosive volcanism. Single grains smaller than $2 \mathrm{~mm}$ in size are termed 'volcanic ash' and those below $64 \mu \mathrm{m}$ are 'extremely fine ash'; fragments of 2-64 $\mathrm{mm}$ are termed 'lapilli', following the physical volcanology-derived definitions of White and Houghton (2006). All the tephra found in the UK during the Eyjafjallajökull and Grímsvötn eruptions is classified as volcanic ash and comprises fragments of volcanic glass and mineral crystals. 'Microtephra' and 'cryptotephra' are terms used in tephrochronology to describe horizons with dispersed ash grains that are too small to be seen by the naked eye, and are identified by laboratory analysis of soils and sediments (Lawson et al.
2012). Here we refer to individual ash fragments as 'grains'. We refer to a 'particle' as any airborne object, which may be a single grain of volcanic ash or an aggregate of grains. Unless otherwise specified, grain lengths or diameters correspond to the long axis of a grain as it appears under the optical or electron microscope. $\mathrm{PM}_{10}$ and $\mathrm{PM}_{2.5}$ refer to airborne particles that pass through the inlet of air sampling equipment with a $50 \%$ collection efficiency at $10 \mu \mathrm{m}$ and $2.5 \mu \mathrm{m}$, respectively.

\section{Eruption characteristics}

The May 2011 subglacial, basaltic eruption of Grímsvötn $\left(64.42^{\circ} \mathrm{N}, 17.33^{\circ} \mathrm{W}\right)$ lasted 7 days and erupted $0.6-0.8 \mathrm{~km}^{3}$ of tephra (Gudmundsson et al. 2012). Sulphur concentration measurements of the tephra indicate that it was triggered by a supply of new magma from depth (Sigmarsson 2012). The eruption began at 19:00 UTC on 21 May with a plume reaching $15-20 \mathrm{~km}$ above sea level, forming a 50$100 \mathrm{~km}$ wide umbrella cloud, which was sustained until late on 22 May (Gudmundsson et al. 2012). From 23 May, the eruption continued at a much lower intensity, with a plume height of less than $10 \mathrm{~km}$ above sea level, until it ended on 28 May (Petersen et al. 2012b).

Proximal deposition onto the Vatnajökull glacier, which covers Grímsvötn volcano, was dominantly from a cloud, 2-4 $\mathrm{km}$ above sea level high that drifted southwards from the base of the eruption plume (See Additional file 1: Figure Sup-I). Approximately 1-2 cm of tephra was deposited in Kirkjubærklaustur, $75 \mathrm{~km}$ to the southsouthwest of the volcano, but there was little deposition from the umbrella region of the plume, which was pale in colour and moved northwards (Gudmundsson et al. 2012). Fine ash-rich and accretionary lapilli-bearing units, where premature deposition was most-likely promoted by aggregation, indicate that the eruption had phreatomagmatic phases, while layers rich in pumiceous lapilli indicate that magmatic fragmentation was also important. Overall, the tephra deposit was similar to that produced in the $0.047 \pm 0.008 \mathrm{~km}^{3}$ (uncompacted) Grímsvötn eruption of 2004 , where $>80 w t \%$ of the tephra was in the ash-size fraction $(<2 \mathrm{~mm})$ and $20 w t \%$ of which was extremely fine ash $(<63 \mu m)$ (Jude-Eton et al. 2012).

\section{Meteorological conditions}

The key factor controlling the dispersal of tephra from the Grímsvötn 2011 eruption was the high wind shear across the Vatnajö kull glacier near the vent region. Close to the surface $(<4 \mathrm{~km}$ above sea level), northerly winds carried tephra southwards from Iceland over the Atlantic, where a number of rain-producing low pressure systems were moving north-eastward along a path between northern Scotland and the Faroe islands (e.g. Bracknell archive synoptic charts: http://www.wetterzentrale.de/topkarten/ fsfaxsem.html). Air mass trajectory models demonstrate 
that air masses that passed over the Grímsvötn eruption site overnight on 21-22 May (Figure 1a) then travelled across the northern part of the UK and onwards to mainland Europe, particularly Scandinavia and Germany. Weather fronts associated with these systems crossed the UK on 22, 23, 26 and 28 May. The deepest system (977 mbar) moved north of Scotland overnight on 23-24 May, and was associated with strong northwesterly winds and heavy rainfall.

At higher altitudes ( $>4 \mathrm{~km}$ above sea level), southerly winds blew across Iceland towards Greenland and Jan Mayen (Figure 1b). $\mathrm{SO}_{2}$ retrievals from the satellite-based Ozone Monitoring Instrument (OMI) suggest that sulphate aerosol separated from the tephra and was carried northwards in this part of the plume (Kerminen et al. 2011). Some of the air mass transported to Greenland was then entrained in an eastward-moving low pressure system that crossed the UK along with a band of rain on 27 May. These meteorological conditions, with rainfall and strong, shifting, winds led to the rapid dispersal of ash. They were very different to the unusually long-lived anticyclonic conditions that prevailed during the Eyjafjallajö kull eruption (Petersen et al. 2012a). This difference, combined with changes in aviation rules in April 2010 and the shorter eruption duration, led to the much lower impact of the Grímsvötn eruption on European aviation.

\section{Tape-on-paper samples collected by the public (citizen science) \\ Method}

Ash samples were collected by the British Geological Survey (BGS) and by volunteers from across the UK (see Additional file 1: Figure Sup-II for map of UK place names). Many were collected using a new method of public sample collection that was developed following the 2010 Eyjafjallajökull eruption. It was designed to be simple and to require only common household items with the intention of getting a large response from across the UK and facilitating rapid analysis. An instruction video was recorded and posted on the BGS website (http://www.bgs.ac.uk/research/ volcanoes/GrimsvotnAshCollection.html) and on a volcanology blog (http://all-geo.org/volcan01010/2011/05/ ash-sampling/). Appeals for samples were made via the BGS Press Office through radio, television, newspapers and social media (Twitter, Facebook) and through the
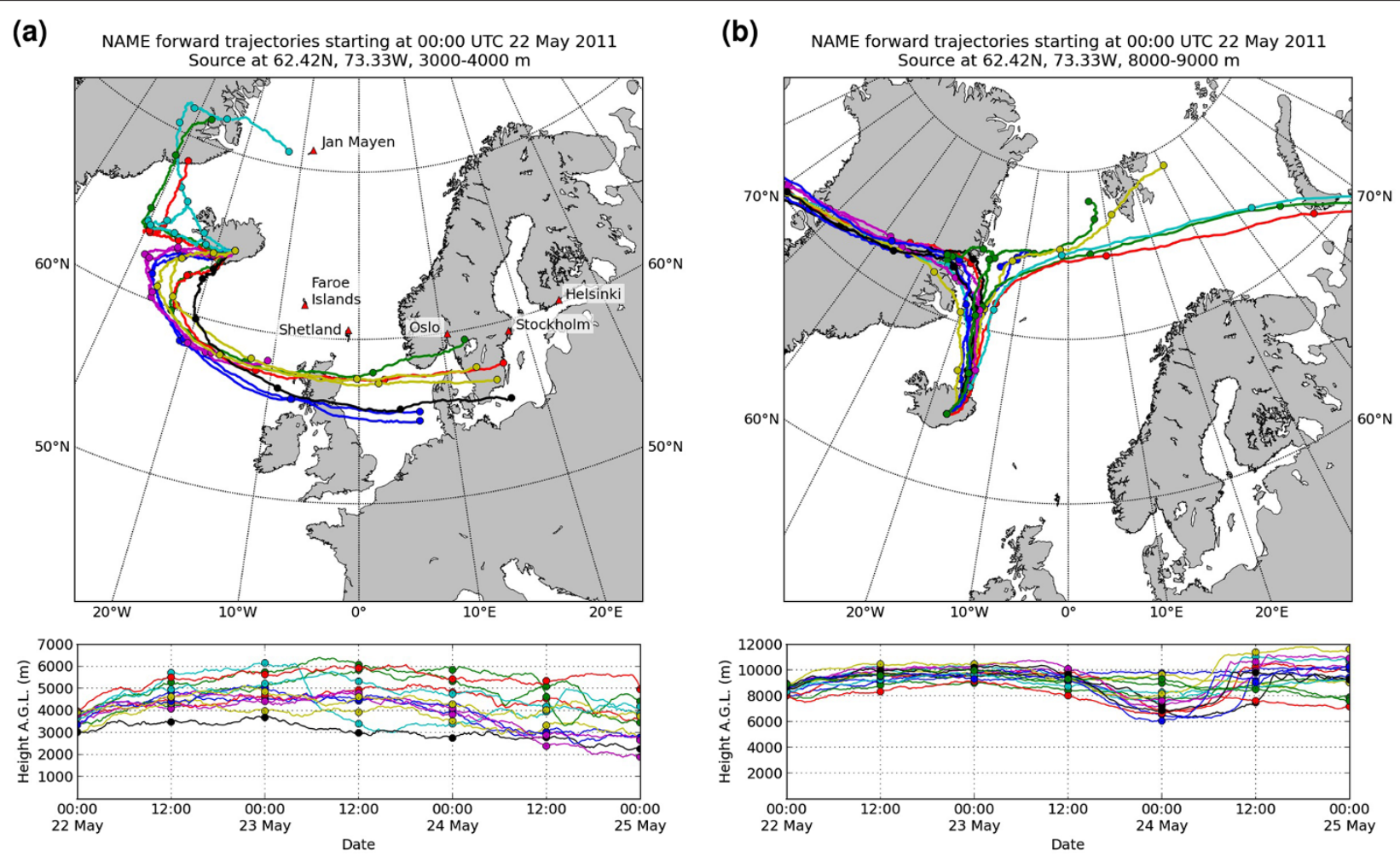

Figure 1 Maps of modelled air mass trajectories, calculated with the NAME Lagrangian dispersion model (Witham et al. 2007). The plots are forward trajectory simulations using the Met Office Global Unified Model on a $25 \mathrm{~km}$ grid. The different paths are produced by releasing particles from different elevations within a $1 \mathrm{~km}$ vertical range. Vertical velocities are taken from the weather model. The purpose of the maps is to give a general impression of wind trajectories from different release heights and they do not include particle settling or other parameters used in dispersion modelling of tephra. The release time, 00:00 on 22 May 2011 is 5 hours after the onset of the eruption, and when the plume was well-established. (a) Release from 3-4 km. (b) Release from 8-9 km. Only particles from the lower part of the eruption column were initially transported towards the UK. 
BGS Outreach Officer (e.g. to the Earth Science Teachers Association).

Participants were asked to fasten sticky-tape to a holder (e.g. a book), sticky-side upwards, and place it outside in an elevated location away from wind-blown surface dust and from tree cover (e.g. on the roof of a car). After a day or so, or at the end of the reported or visible ash fall period, they were asked to stick a strip of plain white office paper over the tape and mark it with with town name, the postal code, and the start and end dates and times of exposure. Participants were also invited to include an email address in order to be updated with results. The samples were posted to the BGS in envelopes marked 'Grímsvötn Ash Sample'. Two other methods were also described on-line (See Additional file 2) that were more complicated and consequently had much lower response rates. The first of these aimed to collect samples suitable for scanning electron microscope (SEM) analysis. It used double-sided tape and required making a protective cardboard housing in which to post the sample. The second method collected wet-deposited ash in a saucepan and required participants to boil off rainwater and collect the remains on sticky-tape. Other samples received were taken directly from car roofs or other surfaces (See Additional file 1: Figure Sup-III), either with sticky tape or with other material e.g. tissue, sponge. These were analysed in the same manner as the tape-on-paper samples, and because the start date was unknown, they were allocated a start time of 18:00hrs on 21 May.

Good quality samples that were clearly identifiable as volcanic ash were analysed by SEM to establish composition and textures. Images from a sample from Kirkwall Grammar School, Orkney $\left(58.98^{\circ} \mathrm{N}, 2.96^{\circ} \mathrm{W}\right)$ were released to the press to further encourage participation by the public. Energy dispersive $\mathrm{x}$-ray spectroscopy (SEM-EDS) gave semi-quantitative composition measurements of individual grains.

The tape-on-paper samples were used like microscope 'slides' and checked for the presence of volcanic ash, which appeared to the naked eye as a dusty brown smudge. Typical analysis takes less than 5 minutes per sample. The tape-on-paper slides are not suitable for highmagnification analysis using transmitted light, but with a reflected light microscope at $75 \times$ magnification, individual grains could be recognised. Ash grains were identified based on the following criteria: $<100 \mu m$ diameter; pale, brownish, translucent colour; angular shape; association with aggregates. At this magnification, bubble-wall shapes and mineral crystals are too small to be observed and definitive identifications are hard to make (Figure 2a), so slides were marked as 'No tephra', 'Possible tephra' or 'Likely tephra'. It is not possible to make quantitative
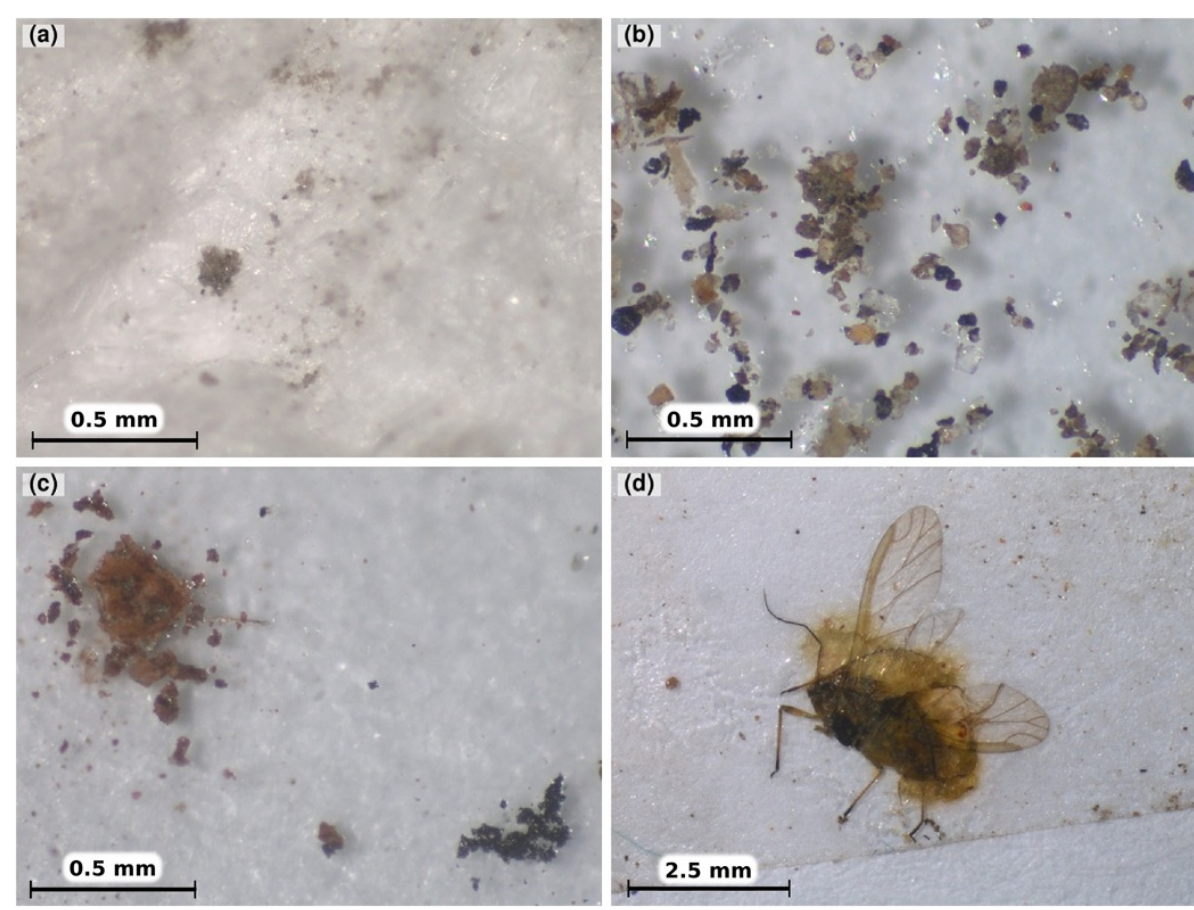

Figure 2 Example images from tape-on-paper slides ( 75x magnification). (a) Volcanic ash in a sample from Lerwick. The grains are very small $(<25 \mu \mathrm{m})$, but still recognisable by their glassy, brownish colour. Often, the grains form aggregates. (b) Mineral grains (non-volcanic). The grains, mainly sand, are blown around by strong winds and are found in most tape-on-paper samples. They vary in shape and size and, in this example, are much larger than the volcanic ash grains (>100 $\mu \mathrm{m}$ ). (c) Black, opaque grains, such as in the bottom right, were common in the tape-on-paper samples and are probably soot. (d) Biological materials, such as pollen, bits of leaf and insects, were also found in most tape-on-paper samples. 
measurements of mass loading or of the intensity of tephra deposition. Soot, organic matter and mineral dust were also present on the slides (Figure $2 b-d$ ). These particles were typically much coarser than $100 \mu \mathrm{m}$, but the smallest grains could have a similar texture to volcanic ash. To reduce the effect of operator bias in such a subjective analysis, time and date information were removed from a subset of 44 samples, which were re-examined 'blind' by two other analysts and the average results were calculated.

\section{Results}

Over 130 tape-on-paper samples were received, spanning most of the UK (an area of approx. $1000 \mathrm{~km} \mathrm{N-S}$ by $500 \mathrm{~km} \mathrm{E-W;} \mathrm{Figure} \mathrm{3a).} \mathrm{Many} \mathrm{of} \mathrm{the} \mathrm{samples} \mathrm{came}$ from primary and secondary schools. Twenty-six slides contained 'Likely tephra' or 'Possible tephra'. In the 'blind' analysis, five of these were unanimously identified as containing tephra by all operators (See Additional file 1: Figure Sup-IV). All 'Likely tephra' samples were found in Scotland $\left(>55^{\circ} \mathrm{N}\right)$. Samples designated 'No tephra' or 'Possible tephra' were found across the UK, including in locations where samples designated 'Likely tephra' were also found. Plotting the time of exposure versus latitude (Figure 3b) shows that all samples with 'Likely tephra' overlap on a period from late 24 May into early 25 May. These samples have different exposure times and it is possible that tephra deposition took place at different times in different locations, but the results are an indication that most deposition took place during this time interval. Preliminary results from these methods were posted on the BGS website in June 2011 (http://www.bgs.ac.uk/ discoveringGeology/hazards/volcanoes/grimsvotn 2011. html) and were distributed to members of the public who had sent in samples.

SEM analysis showed that individual grains of ash varied in texture, ranging from angular and blocky, to broad and flat ('platy') and cuspate (Figure 4). Many were clearly bubble-wall shards. SEM-EDS analysis of glass shards reveal a basaltic composition, with peaks for $\mathrm{Si}, \mathrm{O}, \mathrm{Al}$, $\mathrm{Ca}, \mathrm{Fe}, \mathrm{Mg}$, and show good agreement with reference samples for the eruption collected from proximal locations (See Additional file 1: Figure Sup-V). The various textures demonstrate fragmentation by both magmatic (vesicular grains) and hydromagmatic (blocky, angular grains) processes. Grain sizes range from $<1 \mu \mathrm{m}$ to $60 \mu \mathrm{m}$ in length. Larger particles typically had smaller particles adhering to them. Aggregates of grains were common, some were loose and branching, others were loose clumps. Aggregates were dominated by grains $<30 \mu \mathrm{m}$ in length but also contained a few larger grains. Some aggregates were partially cemented by halite, but the aggregates were significantly less well cemented and less dense than those observed during the 2010 Eyjafjallajökull eruption (Stevenson et al. 2012).

\section{Rainwater samples Identification of tephra Method}

Rainwater samples were collected by Met Office observers at weather stations across the UK (Figure 5). The methods used were based on standard procedures; a $127 \mathrm{~mm}$ diameter rain gauge, placed away from overhanging trees and on an elevated position to avoid splashing, was emptied every 24 hours. The water was placed in a sample bottle labelled with location and dates/times of the collection period and sent to the BGS. Nineteen of the samples, collected on 24-26 May were analysed. Samples were centrifuged, treated with hydrogen peroxide $\left(\mathrm{H}_{2} \mathrm{O}_{2}\right)$ to remove organic material, spiked with a
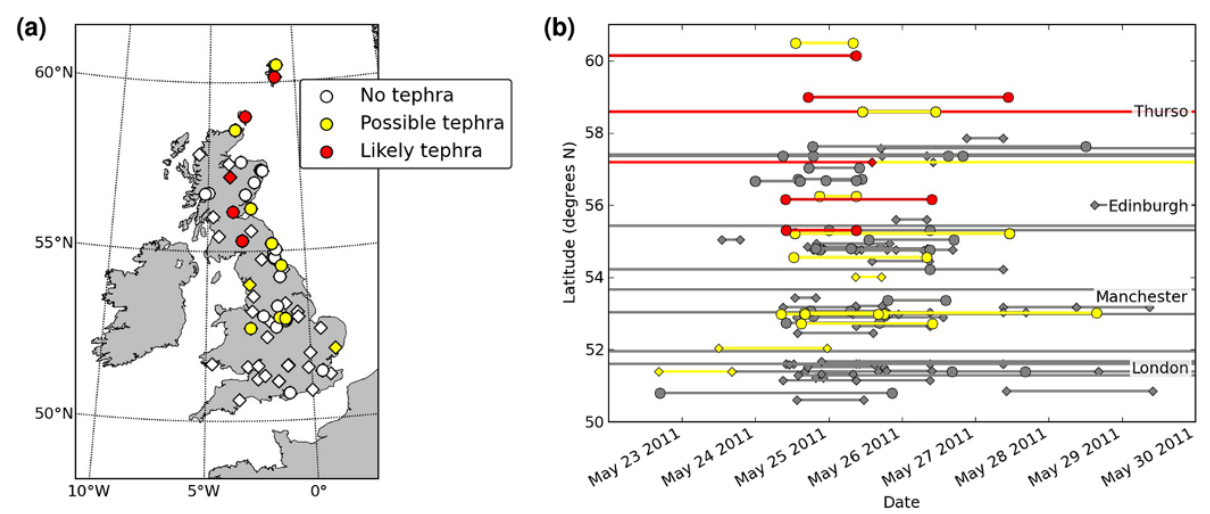

Figure 3 Results of public tape-on-paper sampling. (a) Map of sample locations and presence of tephra. There is good coverage across the UK. All samples with 'Likely tephra' came from Scotland and most samples from southern England were classed 'No tephra'. Data plotted as circles were triple-checked by two 'blind' operators; diamonds were checked once. (b) Plot of sample collection time versus latitude. Each bar represents an individual sample and runs from the exposure start time to the end time. All likely tephra samples overlap on 24 May 2011. 

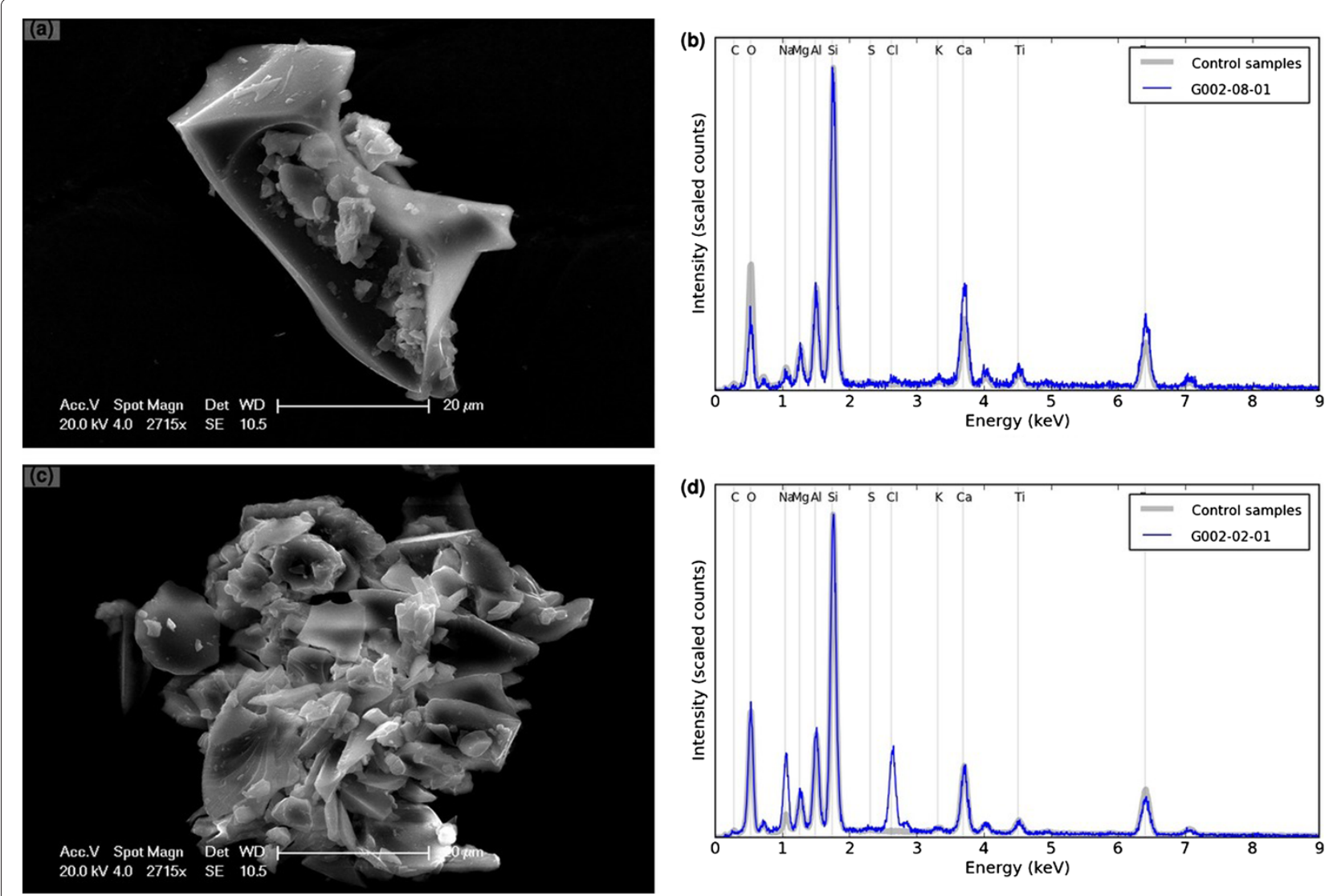

Figure 4 SEM analysis of particles of Grímsvötn tephra deposited at Eskdalemuir on 24-25 May. (a) Typical glass shard, diameter $\sim 40 \mu m$. The cuspate form indicates fragmentation of vesicular magma. (b) SEM-EDS spectrum for shard shown in (a). The intensity is scaled so that the Si-k $\alpha$ peak is the same size for all samples. There is good agreement with reference samples from proximal locations. (c) Aggregate clast, diameter $\sim 60 \mu \mathrm{m}$. Component clasts are bubble-wall fragments 1-20 $\mu \mathrm{m}$. (d) SEM-EDS spectrum for aggregate clast shown in (c). There is good agreement with reference samples from proximal locations and increased proportions of sodium $(\mathrm{Na})$ and chlorine $(\mathrm{Cl})$.

Lycopodium clavatum tablet and mounted with Naphrax (a mounting medium with similar refractive index to silica), following the method of Stevenson et al. (2012). The Lycopodium tablets contain a known number of spores and allow grain counts in subsamples to be related to the sample total. Independently, rainwater samples were collected in buckets in Auldearn $\left(57.59^{\circ} \mathrm{N}, 3.87^{\circ} \mathrm{W}\right)$ and Fair Isle $\left(59.53^{\circ} \mathrm{N}, 1.63^{\circ} \mathrm{W}\right)$ on $23-24$ May. In these samples, the water was removed by passing the samples through a $5 \mu m$ nylon sieve mesh, then a subsample was mounted with Canada Balsam.

Tephra slides were examined using a petrological microscope under plane-polarised light at $500 \times$ magnification. Tephra grains were identified on the basis of their brown colour, angular shape, isotropic character and the presence of bubbles and crystals within them. Grains were measured using the microscope graticule. Mass loading estimates were obtained by counting volcanic ash grains relative to $\geq 300$ Lycopodium spores, following Stevenson et al. (2012). With this method, it is difficult to identify grains $<10 \mu m$, which are too small to contain bubbles or crystals, thus such particles were not included in the counts. Typical analysis, including preparation time, takes over 3 hours per sample. Selected samples were also analysed by scanning electron microscope (SEM). Drops of concentrated tephra/Lycopodium mixture were dried onto carbon stubs, then carbon coated.

\section{Results}

Volcanic ash was confidently identified in Northallerton (NE England), Armagh (N Ireland) and Lerwick (Shetland, $160 \mathrm{~km}$ north of mainland Scotland), and possibly identified in other locations in Scotland, N England and as far south as Ipswich (SE England). Table 1 and Figure 5 summarise the results. Samples collected on 24-25 May contained the most tephra, but it was also found in samples collected on 26-27 May. The sizes of measured grains had modes of 25-30 $\mu \mathrm{m}$ although grains $<10 \mu \mathrm{m}$ were not counted, and those close to this minimum size were more likely to be missed. Furthermore, aggregate 


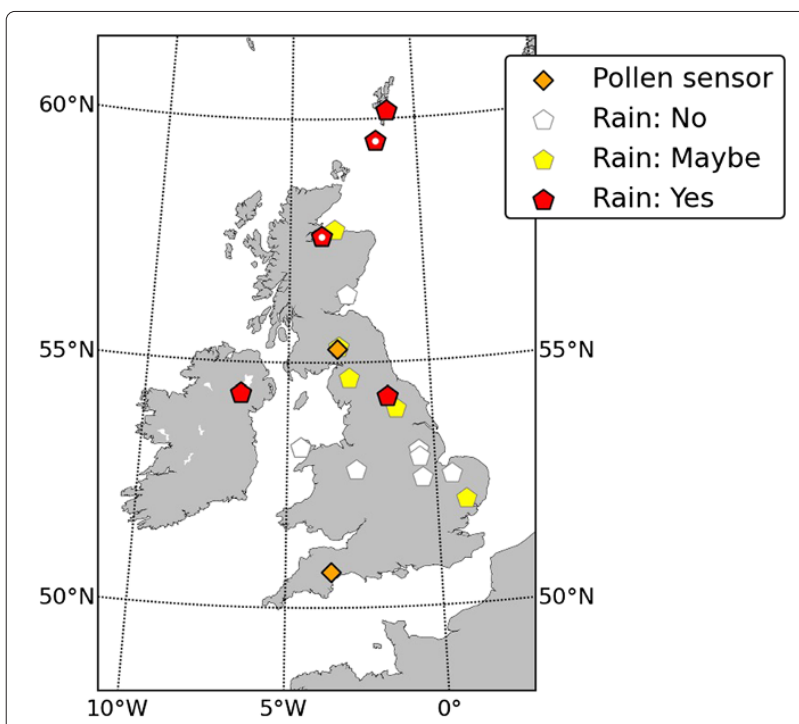

Figure 5 Map of UK rainwater and pollen samples. Locations where tephra was identified have thick black outlines. Rainwater samples that were not collected as part of the Met Office network are marked with a white dot. Tephra was identified at both pollen sites.

clasts that broke into grains of $<10 \mu m$ will also have been missed. Grain counts relative to Lycopodium spores correspond to a maximum of 116 grains $\mathrm{cm}^{-2}$. Small isotropic grains were present in all samples that contained tephra, but could not be definitively identified as volcanic glass. Mineral grains, which represent wind-blown dust contamination were also present in all samples, as was also the case during the 2010 Eyjafjallajökull eruption (Stevenson et al. 2012). Ash was also present in the Auldearn and Fair Isle samples (Table 1) where the modal grainsize was $25 \mu \mathrm{m}$ and the largest grains were up to $80 \mu \mathrm{m}$ in diameter. The shapes of the larger grains were dominated by bubble-wall shards and Y-shaped or cuspate grains were common (Figure 6). These grain shape characteristics are consistent with tephra produced by the fragmentation of a gas-rich, vesicular magma, with vesicles $5-<50 \mu m$.

SEM results confirmed the dominance of bubble-walltype grain morphologies and documented the presence of aggregate clasts comprising fragments 1-20 $\mu \mathrm{m}$ in diameter. SEM-EDS analysis of glass shards reveal a basaltic composition, with peaks for $\mathrm{Si}, \mathrm{O}, \mathrm{Al}, \mathrm{Ca}$, $\mathrm{Fe}, \mathrm{Mg}$, in good agreement with the reference samples from proximal locations. Aggregate grains have elevated proportions of $\mathrm{Na}$ and $\mathrm{Cl}$, which may result from interaction with salts derived from sea water. SEM-EDS analysis also identified a range of mineral grains (quartz, feldspar) that likely represent contamination by local soils. Quartz and feldspar grains were also found in rainwater samples collected during the 2010 Eyjafjallajökull eruption (Stevenson et al. 2012).
Wind-blown dust and sea salt grains are commonly found in the $\mathrm{PM}_{10}-\mathrm{PM}_{2.5}$ fraction of urban airborne particles in the UK (Harrison and Jones 1995).

\section{Chemical analysis}

In addition to the tephra identification described in the Rainwater samples Method section, the Scottish Environment Protection Agency (SEPA) analysed the chemistry of rainwater samples. These samples were collected by SEPA's network of public volunteers that was set up during the 2010 Eyjafjallajökull eruption, as well as from nine SEPA offices across Scotland. Samples were analysed following standard and fully accredited methods (e.g. Great Britain - Standing Committee of Analysts 1978) for $\mathrm{pH}$ and fluorine (F) concentration (as potential indicators of acidic volcanic inputs and because volcanic fluorine has been associated with poisoning of livestock; Cronin et al. 1998). A subset of samples was also analysed for iron $(\mathrm{Fe})$, manganese $(\mathrm{Mn})$, chlorine $(\mathrm{Cl})$ and aluminium (Al), which are commonly found in soluble sulphate and halide salts adsorbed to the surface of tephra grains (Ayris and Delmelle 2012; Bellomo et al. 2003; Jones and Gislason 2008) and the results are presented in Table 2. These samples are not routinely collected so no reference data for background concentrations are available and the elements analysed in each sample varied, but samples with an iron concentration of $>1 \mathrm{mg} \mathrm{l}^{-1}$ were deemed to have anomalously high concentrations. A large potential source of error in measurements of the concentration of metals is that rainwater samples are subject to dilution caused by additional rainfall after tephra deposition (i.e. further rain after the plume has passed but before the rain gauge is emptied for sampling), and that the amount of rainfall varies across different locations.

There was no indication of volcanic contamination in the $\mathrm{pH}$ and $\mathrm{F}$ results, and the quantities of deposited ash were too small to smother foods or cause physical harm e.g. tooth abrasion, so the eruption presented no threat to livestock (Cronin et al. 1998; SEPA 2011). A number of samples had anomalously high Fe contents (see Table 1). All of these had been collected in northern Scotland between 24 and 27 May (Figure 7). Daily time series data from Shetland from 24-30 May show a greater than 10-fold increase in $\mathrm{Fe}$ and $\mathrm{Mn}$ concentration in rainwater collected between 08:00 on 24 May and 08:00 on 25 May compared to the other days (SEPA 2011). There is strong covariance between $\mathrm{Fe}$ and $\mathrm{Al}$ concentration, and each site with anomalously high Fe also contained $>1 m g l^{-1} \mathrm{Al}$, suggesting a common source. This relationship is absent between Fe and Mn concentrations (which are much lower) and $\mathrm{Fe}$ and $\mathrm{Cl}$ concentrations (which may be influence by seawater-derived $\mathrm{NaCl}$ ). 
Table 1 Results of analysis of rainwater samples

\begin{tabular}{|c|c|c|c|c|c|c|c|}
\hline Sample & Location & Lon. $\left({ }^{\circ} \mathrm{E}\right)$ & Lat. $\left({ }^{\circ} \mathbf{N}\right)$ & Sample period & $\begin{array}{l}\text { Tephra } \\
\text { present }\end{array}$ & Grainsize $(\mu \mathrm{m})$ & Grain count $\left(\mathrm{cm}^{-2}\right)$ \\
\hline G007 & Lerwick & -1.14 & 60.15 & $24 / 05-24 / 05$ & Yes & $20-25$ & 116 \\
\hline G025 & Leuchars & -2.88 & 56.38 & 25/05-26/05 & No & & \\
\hline G027 & Armagh & -6.65 & 54.35 & $24 / 05-27 / 05$ & Yes & $20-25$ & 50 \\
\hline G029 & Ipswich & 0.97 & 52.12 & $26 / 05-27 / 05$ & Maybe & & \\
\hline G090 & Norfolk & 0.55 & 52.66 & $24 / 05-27 / 05$ & No & & \\
\hline G093 & Northallerton & -1.52 & 54.29 & 26/05-27/05 & Yes & $25-30$ & 18 \\
\hline G095 & Shawbury & -2.66 & 52.80 & 26/05-26/05 & No & & \\
\hline G119 & Anglesey & -4.54 & 53.25 & $25 / 05-26 / 05$ & No & & \\
\hline G120 & Anglesey & -4.54 & 53.25 & $26 / 05-27 / 05$ & No & & \\
\hline G125 & Waddington & -0.53 & 53.17 & $26 / 05-26 / 05$ & No & & \\
\hline G126 & Waddington & -0.53 & 53.17 & $26 / 05-27 / 05$ & No & & \\
\hline G132 & Lossiemouth & -3.31 & 57.71 & $25 / 05-26 / 05$ & Maybe & & \\
\hline G136 & Eskdalemuir & -3.20 & 55.31 & $24 / 05-25 / 05$ & No & & \\
\hline G137 & Eskdalemuir & -3.20 & 55.31 & 25/05-26/05 & Maybe & & \\
\hline G149 & RAF Wittering & -0.44 & 52.61 & $26 / 05-27 / 05$ & No & & \\
\hline G162 & Cranwell & -0.51 & 53.03 & $26 / 05-27 / 05$ & No & & \\
\hline G170 & Yorkshire & -1.25 & 54.04 & 26/05-27/05 & Maybe & & \\
\hline G177 & Penrith & -2.85 & 54.67 & 25/05-29/05 & Maybe & $<10$ & Many \\
\hline G-AM1 & Auldearn & -3.80 & 57.58 & 23/05-29/05 & Yes & Many $>50$ & \\
\hline G-AM2 & Fair Isle & -1.63 & 59.53 & 23/05-24/05 & Yes & $25(\operatorname{Max} 80)$ & \\
\hline G-AM3 & Fair Isle & -1.63 & 59.53 & 24/05-24/05 & Yes & $25(\operatorname{Max} 80)$ & \\
\hline
\end{tabular}

Samples G007-G170 were from rain gauges as part of the Met Office network, and were changed at daily at 09:00.

Samples G-AM1-G-AM3 were collected in a bucket.

\section{Pollen slides Method}

Pollen slides collected by the Met Office pollen monitoring network were checked for volcanic ash. The network comprises 18 stations across the UK, of which approximately half operate throughout the pollen season from March to September, whilst the remainder only monitor during the May-July grass pollen season. During the Grímsvötn eruption, slides from two of these stations were examined.

The sites operate Hirst-Burkard volumetric spore traps (Käpylä and Penttinen 1981), positioned on rooftop sites where they are able to sample free air uncontaminated by localised sources. The basic mechanical design of the traps has changed little since they were introduced in the 1950s. A wind vane keeps the trap pointing into the wind, and a pump draws air into the trap through an orifice measuring $2 \mathrm{~mm} \times 14 \mathrm{~mm}$ at a rate of 10 litres per minute. Inside the trap, the air stream meets a $20 \mathrm{~mm}$ wide revolving drum covered in transparent tape, which is itself covered with a very thin layer of petroleum-jelly adhesive. Particles drawn in through the orifice are trapped by the adhesive. The pollen trap is largely unaffected by the weather, but in severe conditions of driving rain it is possible for a sample to become drenched.

The drum revolves at $2 \mathrm{~mm}$ per hour and the tape was replaced at 09:00 each day. The tape from a 24-hour catch occupies an area of $48 \mathrm{~mm} \times 20 \mathrm{~mm}$, and is mounted on a standard microscope slide for analysis. The tape is mounted to the slide using glycerin jelly stained red with fuchsin, which makes organic pollen grains stand out against other inorganic particles (like volcanic ash). Too much fuchsin, however, can make it difficult to see tephra grains. The prepared microscope slides were analysed in 12 transects, each $4 \mathrm{~mm}$ apart, to identify pollen and tephra grains and to ascertain the approximate time of the capture of various particles by the trap. Typical analysis takes up to 15 minutes per sample.

\section{Results}

Pollen slides from Eskdalemuir, southern Scotland $\left(55.27^{\circ} \mathrm{N}, 3.25^{\circ} \mathrm{W}\right)$, and Exeter, southern England $\left(50.72^{\circ} \mathrm{N}, 3.53^{\circ} \mathrm{W}\right.$ ), were available to be analysed (see Figure 5 for locations). The grains in these samples were too small to contain crystals or vesicles, but could be identified as volcanic ash by their transparent colour, 


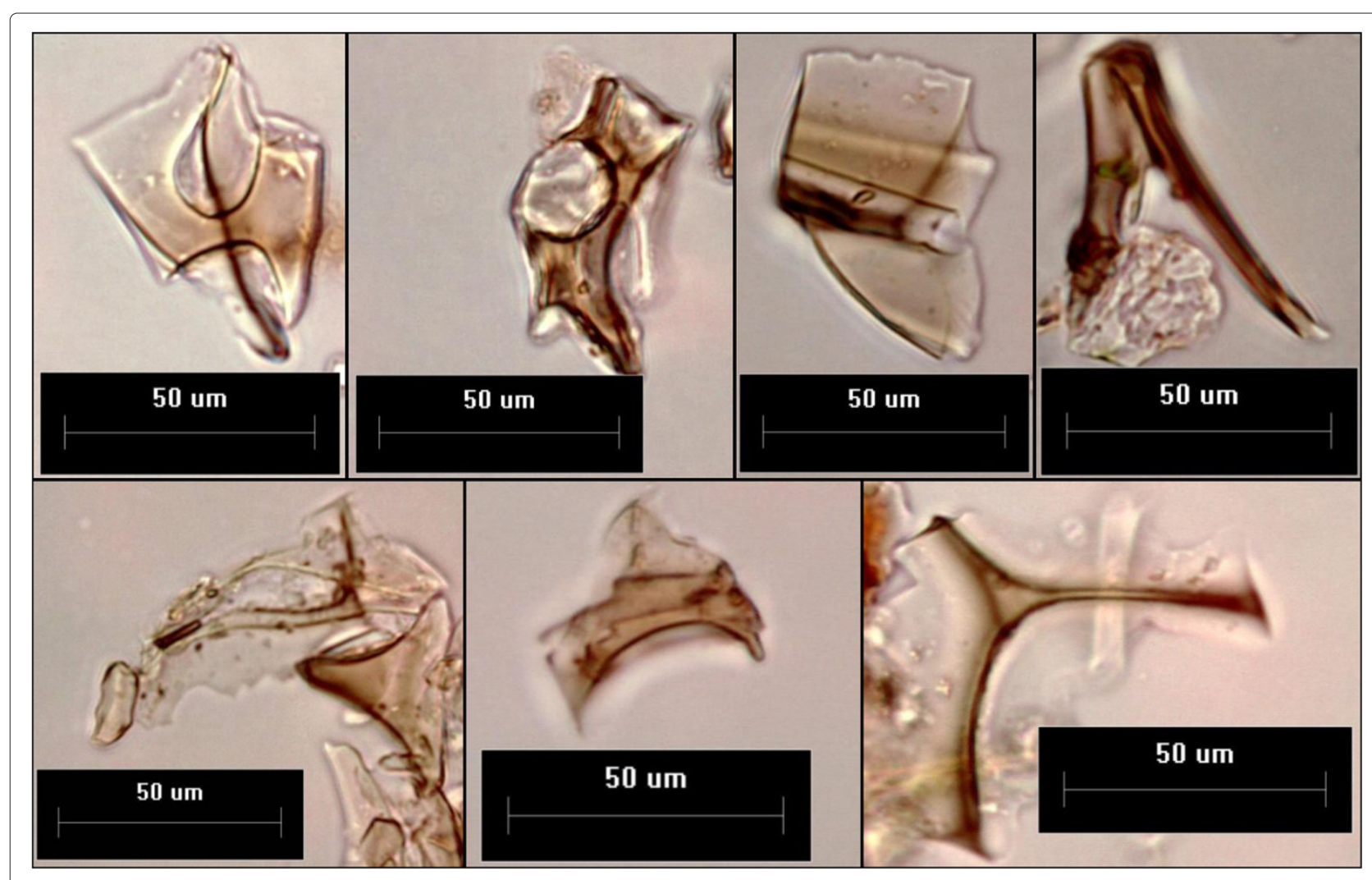

Figure 6 Grímsvötn tephra shards collected in rainwater in the UK. Those in the top row were collected in Auldearn; those in the bottom row were collected on Fair Isle. Grains are brown-coloured and dominated by bubble-wall shards indicating fragmentation of a vesicular magma with bubble diameters of 5 to $50 \mu \mathrm{m}$.

angular shape and occurrence in large numbers at specific time intervals of the slides. On some slides, grains form rings around $50 \mu \mathrm{m}$ in diameter, each containing 50-100 grains (Figure 8). These are interpreted to have formed when tephra-filled raindrops were collected on the tape.

Tephra was detected at Eskdalemuir from 19:30 on 23 May until 15:00 on 24 May. Deposition was most intense from 20:30-22:00 on 23 May, peaking at 21:45. There was further deposition of small quantities from 13:0021:00 on 27 May. The grainsize was measured using image analysis with the ImageJ software package (see Additional file 1: Figure Sup-VI). The modal length of 103 grains was $3.9 \mu \mathrm{m}$. As pollen grains themselves, with diameters of $\sim 30 \mu \mathrm{m}$ were also collected, it is assumed that the lack of larger ash particles reflects the true state of the air and is not an artefact of the sampling method. Small, transparent, angular grains were also detected at Exeter on the morning of 24 May. To determine their composition, the contents of the Exeter slide were washed from the glass with warm deionised water, then processed as per the rainwater samples (see the Rainwater samples

Table 2 Results of chemical analysis of rain gauge samples from Scotland

\begin{tabular}{|c|c|c|c|c|c|c|c|}
\hline Location & Lon. $\left({ }^{\circ} \mathrm{E}\right)$ & Lat. $\left({ }^{\circ} \mathrm{N}\right)$ & Sample period end & $\mathrm{Fe}\left(m g l^{-1}\right)$ & $M n\left(m g l^{-1}\right)$ & $\mathrm{Cl}\left(m g l^{-1}\right)$ & $\mathrm{Al}\left(m g l^{-1}\right)$ \\
\hline Thurso & -3.55 & 58.60 & $24 / 05-08: 00 \mathrm{hrs}$ & 2.51 & 0.0456 & - & 1.77 \\
\hline Stornoway & -6.31 & 58.20 & $24 / 05-15: 00 \mathrm{hrs}$ & 1.86 & 0.0846 & - & - \\
\hline Elgin & -3.29 & 57.64 & 24/05 - 15:00 hrs & 5.78 & 0.0359 & 8.20 & 5.59 \\
\hline Dingwall & -4.44 & 57.61 & 25/05 - 12:00 hrs & 3.85 & 0.0730 & 15.10 & 2.63 \\
\hline Dingwall & -4.44 & 57.61 & $27 / 05-15: 00 \mathrm{hrs}$ & 3.60 & 0.2430 & 4.85 & 2.64 \\
\hline Orkney & -2.97 & 58.99 & $26 / 05-15: 00 \mathrm{hrs}$ & 1.96 & 0.0772 & 3.82 & 1.35 \\
\hline Shetland & -1.32 & 59.93 & $25 / 05-08: 00 \mathrm{hrs}$ & 6.20 & 0.1170 & - & 4.24 \\
\hline
\end{tabular}

The table records locations where anomalously high iron concentrations were observed $\left(\mathrm{Fe}>1 \mathrm{mg}^{-1}\right)$. See SEPA (2011) for full results. No data available for samples marked - 


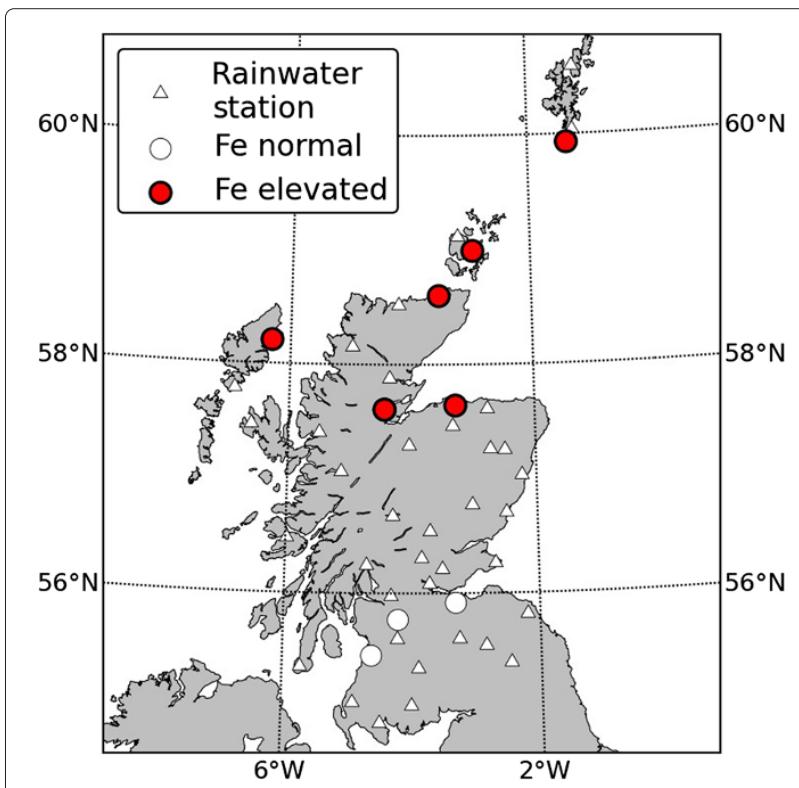

Figure 7 Map of SEPA rainwater chemistry stations. No stations recorded significant anomalies in $\mathrm{pH}$ or fluorine concentration. The concentration of iron and other elements was measured at stations marked by circles. Stations with anomalously high iron (Fe) concentrations $\left(>1 \mathrm{mgl}^{-1}\right.$ ) on 24-27 May are coloured red.

Method section) for SEM analysis. SEM-EDS measurements showed that $40 \%$ of grains had a tephra-like composition, $24 \%$ were quartz, $22 \%$ were feldspar and $14 \%$ were 'other'. As with the rainwater samples, it is likely that mineral grains represent contamination by wind-blown dust (e.g. Harrison and Jones 1995) and it is possible that this is also the case at Eskdalemuir. Grain sizes in Exeter were also measured; the modal long and short axis lengths of the grains with tephra composition were, respectively, $5 \mu m$ and $3.5 \mu m$.

\section{Air quality monitoring Methods \\ Measurements of airborne particulate matter (PM)}

The concentration of airborne particulate matter was measured by TEOM and TEOM-FDMS instruments that are run as part of the UK's Automatic Urban and Rural Network (AURN) and for the Scottish Air Quality Database (SAQD). Hourly mean concentrations of $\mathrm{PM}_{10}$ and $\mathrm{PM}_{2.5}$ are recorded continuously across the UK. Detailed descriptions of how the instruments work are given in Additional file 3. Air quality data were also collected at a number of sites by the Scottish Environment Protection Agency using Osiris instruments, which use a light-scattering approach and have a maximum grainsize of $20 \mu \mathrm{m}$. Osiris measurements are not equivalent to EU reference measurements for $\mathrm{PM}_{10}$ and $\mathrm{PM}_{2.5}$ but they can provide good indicative data. As these results are less well-constrained, they are treated separately.

\section{Estimation of non-primary $P M_{10}$ and $P M_{2.5}$}

In order to distinguish volcanic PM from that from man-made (primary) sources, the concentrations of nonprimary PM was estimated from AURN FDMS instruments. First, the PM associated with primary combustion sources (e.g. traffic) was quantified using measurements of nitrogen oxides $\left(\mathrm{NO}_{X}\right)$ as a tracer. The remaining part, the non-primary PM, is therefore associated with natural sources (including tephra from the eruption) and secondary PM sources (sulphate, nitrate and anthropogenic oxidised particles). Further details about the methodology can be found in Fuller et al. (2002) and Fuller and Green (2006), with details specific to this study given in Additional file 3.

The 95th percentile for $\mathrm{PM}_{10}$ and the 65th percentile for $\mathrm{PM}_{2.5}$ were calculated from the non-primary PM data set for 2011 and these values were used as thresholds to identify episodes of high non-primary $\mathrm{PM}_{10}$ and $\mathrm{PM}_{2.5}$. A greater threshold was selected for $\mathrm{PM}_{10}$ reflecting the frequency of local sources such as construction activities that can affect $\mathrm{PM}_{10}$ but not $\mathrm{PM}_{2.5}$ (Fuller and Green 2004). A total of 45 air quality monitoring stations were used to identify the possible presence of volcanic ash in the air in the UK.

\section{Results \\ Total PM}

The peak total PM concentrations (all sources) from 2324 May and 25-29 May are shown in Figure 9. These two time periods are separated by a period of southerly winds associated with a depression crossing the UK on 25-26 May. A cluster of peaks with concentrations $>100 \mu \mathrm{g} \mathrm{m}$ were found across central Scotland during both periods. The highest recorded hourly concentration was

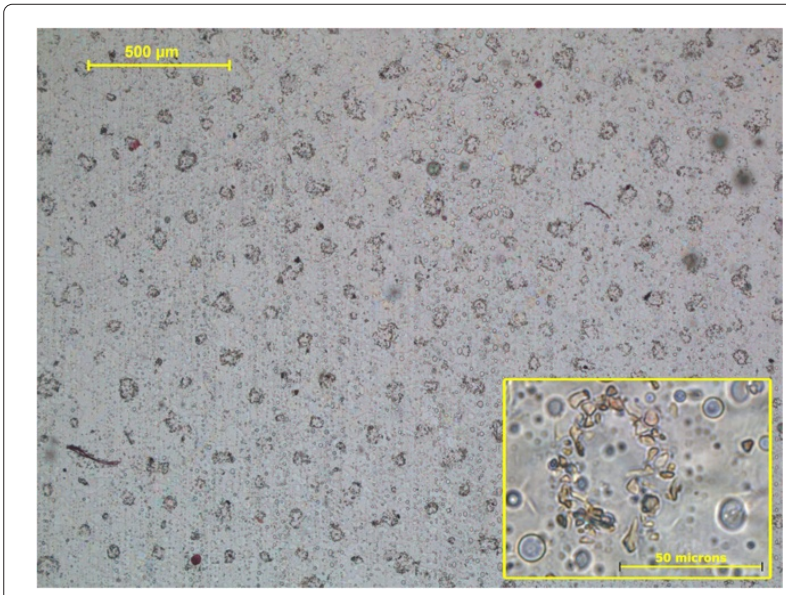

Figure 8 Grímsvötn tephra collected on pollen slides. Grains deposited in raindrops in Exeter, UK, on 25 May 2011. Rings are 50 $\mu \mathrm{m}$ wide and contain 50-100 grains with a modal diameter of $4 \mu \mathrm{m}$ (see inset). 

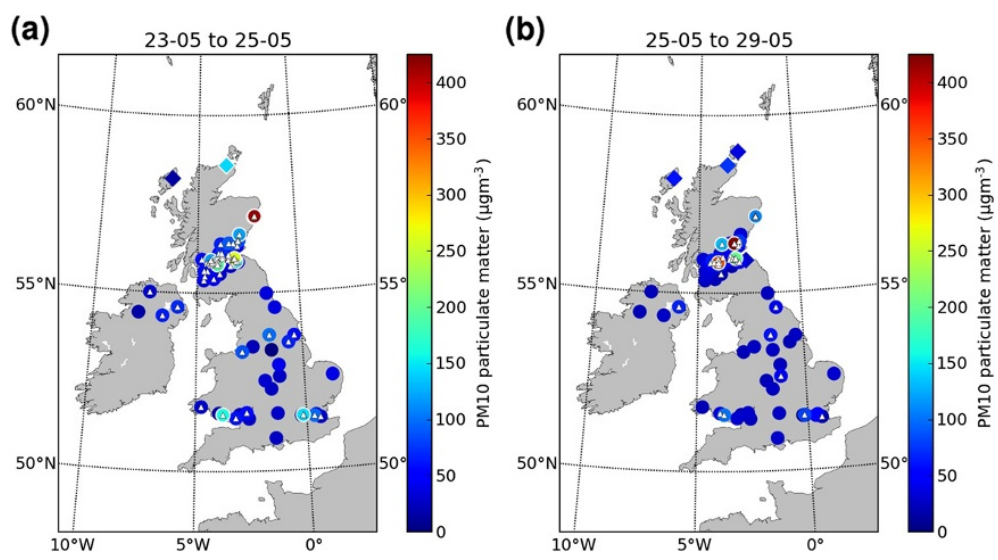

Figure $9 \mathbf{P M}_{10}$ spikes across the UK. Circles are data from AURN and SAQD. Diamonds are from SEPA Osiris units, which were only operational for part of the study period. Locations where $\mathrm{PM}_{10}$ was $>100 \mu \mathrm{g} \mathrm{m}^{-3}$ have white outlines. Triangles mark locations where $\mathrm{PM}_{10}$ measurements were in the 95th percentile for the period 1 April-30 June. (a) Maximum hourly $\mathrm{PM}_{10}$ concentration across the UK from 23-24 May 2011. The highest value was recorded in Aberdeen, with a cluster of elevated values $\left(>100 \mu \mathrm{g} \mathrm{m}^{-3}\right)$ in Central Scotland. (b) Maximum hourly PM $\mathrm{M}_{10}$ concentration across the UK from 25-29 May 2011. There was a cluster of elevated values $\left(>100 \mu \mathrm{g} \mathrm{m}^{-3}\right)$ in Central Scotland.

$413 \mu \mathrm{g} \mathrm{m}^{-3}$ in Aberdeen $\left(57.15^{\circ} \mathrm{N}, 2.09^{\circ} \mathrm{W}\right)$ at $02: 00 \mathrm{hrs}$ on 24 May during the first period and $443 \mu \mathrm{g} \mathrm{m}^{-3}$ in Perth $\left(56.39^{\circ} \mathrm{N}, 3.43^{\circ} \mathrm{W}\right)$ at $11: 00$ on 26 May during the second period. Values of $>100 \mu \mathrm{g} \mathrm{m} \mathrm{m}^{-3}$ were recorded in London $\left(51.51^{\circ} \mathrm{N}, 0.13^{\circ} \mathrm{W}\right)$ and Swansea $\left(51.62^{\circ} \mathrm{N}, 3.94^{\circ} \mathrm{W}\right)$. These data, however, are total concentrations of anthropogenic and natural primary and secondary sources and do not unequivocally denote volcanic origin (see also Additional file 1: Figure Sup-VII for context). For example, the peak in Aberdeen on 24 May is measured in a number of surrounding stations and is likely to be tephra, but the high value in Perth High Street on 26 May is not. Although $\mathrm{PM}_{10}$ samplers do not completely exclude large particles, their collection efficiency for particles $>11 \mu \mathrm{m}$ is less than 10\% (Van Osdell 1991; Wilson et al. 2002). Suspended particle measurements from Osiris units, which have an upper size limit of $20 \mu \mathrm{m}$, in Thurso $\left(58.98^{\circ} \mathrm{N}, 3.52^{\circ} \mathrm{W}\right)$ indicate that a significant part of the plume was coarser than $10 \mu m$ (SEPA 2011). The fraction of $\mathrm{PM}_{10}$ in the suspended particle concentration dropped to $37 \%$ at $20: 26 \mathrm{hrs}$ on 24 May, in comparison to the 5-day mean value of $83 \%$. The proportion of particles coarser than $20 \mu \mathrm{m}$ is not known. Hourly $\mathrm{PM}_{10}$ concentrations at ground level did not exceed the $2000 \mu \mathrm{g} \mathrm{m}^{-3}$ threshold where aviation is restricted, however these measurements are not directly comparable to total tephra concentrations at higher altitudes.

\section{Non-primary $P M$}

Tephra, where present, makes up part of the non-primary component of PM. Figure 10a,b shows the concentration of total and primary PM at the Leeds Headingley Kerbside station $\left(53.80^{\circ} \mathrm{N}, 1.55^{\circ} \mathrm{W}\right)$ during the eruption.
The highest peaks in total $\mathrm{PM}_{10}$ have no corresponding peaks in primary $\mathrm{PM}_{10}$, indicating the possibility that they are dominated by tephra. The non-primary $\mathrm{PM}_{10}$ had a maximum concentration of $75 \mu \mathrm{g} \mathrm{m} \mathrm{m}^{-3}$, which occurred at 13:00 on 24 May and lasted for 1 hour. This behaviour contrasted with anthropogenic non-primary PM which mainly arises from secondary formation and consequently shows only gradual changes in concentrations. At the same time $\mathrm{PM}_{2.5}$ showed a peak of $28.2 \mu \mathrm{g} \mathrm{m}^{-3}$ in the non-primary component.

Figure 10c shows the sites that registered non-primary PM episodes on 24 May. These sites are found in Scotland, Northern Ireland, and the north of England. The colour represents the timing of the peak concentration. The data suggest that the plume arrived in Aberdeen at 03:00 on 24 May, crossed Scotland and N Ireland between 08:00 and 09:00, and spread in a south-easterly direction to reach $\mathrm{N}$ England around 12:00-13:00 on the same day.

\section{Discussion}

\section{Comparison of methods}

Monitoring and measurement of distal ash deposition is important from both an operational and a research perspective. The key questions are where, when and how much ash falls. In addition, data on grainsize, chemical composition and aggregation are important for understanding health and environmental impacts, volcanological processes and dispersion modelling. Other considerations in developing a monitoring strategy are whether techniques can record wet deposition and the trade-off between temporal resolution and signal strength. This study reports results from a number of different sample collection methods, used at a distance of 

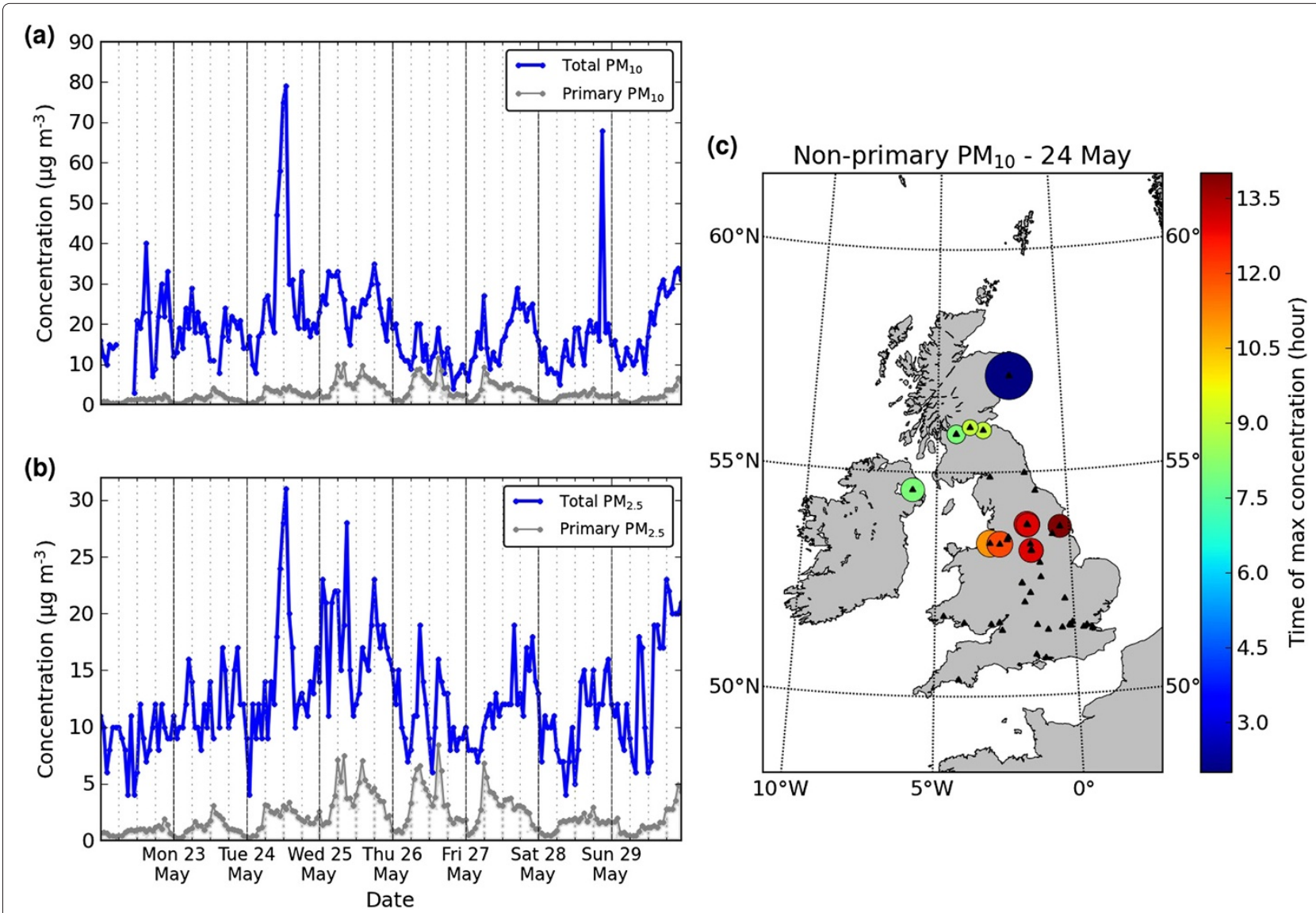

Figure 10 Total and non-primary concentrations of (a) $\mathrm{PM}_{10}$ and (b) $\mathrm{PM}_{\mathbf{2 . 5}}$ in Leeds on 22-30 May 2011. The peak in total $P M_{10}$ on $24 \mathrm{May}$ has a corresponding peak in total $\mathrm{PM}_{2.5}$, but not in primary $\mathrm{PM}_{10}$ or $\mathrm{PM}_{2.5}$. This indicates a non-anthropogenic source with a range of grain sizes e.g. tephra. The peak in total $\mathrm{PM}_{10}$ on 28 May has no corresponding peak in $\mathrm{PM}_{2.5}$. (c) Map of sites where peak hourly non-primary $P M_{10}$ and $P M_{2.5}$ concentrations were higher than the annual 95th and 65th percentiles, respectively, during 24 May. Circle size is proportional to concentration and colour represents the time of day when peaks occurred. The timing of peak concentration increases southwards and also eastwards across England.

1000-1500 km from the volcano following a large (0.6$0.8 \mathrm{~km}^{3}$; Volcano Explosivity Index 4) eruption, where mass loadings are low (often below visible detection limit) and the dominant grainsize is $<50 \mu \mathrm{m}$.

Each method has the potential to confirm the presence of volcanic ash. The absence of ash at a given location is more difficult to demonstrate, because deposition is patchy and because each method is only sensitive to a limited range of grainsizes (e.g. tape-on-paper and rainwater samples measure coarser grains $(>10$ $20 \mu \mathrm{m})$, but air quality sensors measure the finest grains $(<10 \mu m)$.

Data quality depends upon the distinction between volcanic ash and contamination by other airborne particulate matter. If sufficient tephra grains are present in physical samples, and they are large enough to show textural features such as bubbles, then identification is relatively straightforward with a petrological microscope. If grains are few or small (or, in the case of pollen slides, a petrological microscope cannot be used) then SEM analysis can be used, but at significantly increased cost and time per sample. Where this is not possible, the analysis becomes more subjective and the context of a sample can be important in deciding whether grains are volcanic or not. In this case, 'blind' analysis by multiple operators is recommended. For PM data, estimation of the non-primary component reduces the problem of contamination, and this should be used whenever concurrent $\mathrm{PM}_{10}, \mathrm{PM}_{2.5}$ and $\mathrm{NO}_{X}$ data are available.

It is also important to consider exposure times of samples. Short exposures of multiple samples can increase the precision of the timing of the onset and end of deposition, but methods such as the tape-on-paper and rainwater samples often require larger quantities of tephra to be present before a firm identification can be made. If the primary aim is to determine where tephra fell, longer exposures (2-7 days) are preferable. Grain counts from longer exposures are also more comparable to values in the tephrochronology literature, which represent the entire duration of an eruption. 
Table 3 Comparison of different methods and their results

\begin{tabular}{|c|c|c|c|c|c|c|}
\hline Method & Operator & Grainsize & Coverage & Advantages & Disadvantages & Results \\
\hline $\begin{array}{l}\text { Tape-on-paper } \\
\text { samples }\end{array}$ & Public & $>20 \mu \mathrm{m}$ & 87 locations & $\begin{array}{l}\text { Wide coverage; quick and easy to } \\
\text { analyse; ad-hoc network created } \\
\text { quickly. }\end{array}$ & $\begin{array}{l}\text { No further analysis possible; effect } \\
\text { of rain on tape unknown; possible } \\
\text { local contamination. }\end{array}$ & $\begin{array}{l}\text { Tephra identified in Scotland on } \\
\text { 23-24 May }\end{array}$ \\
\hline $\begin{array}{l}\text { Rainwater } \\
\text { (tephra } \\
\text { samples) }\end{array}$ & Met Office (+ public) & $>10 \mu \mathrm{m}$ & 21 locations & $\begin{array}{l}\text { Can record grainsize and mass load- } \\
\text { ing of wet and dry deposition; small } \\
\text { additional cost to existing network; } \\
\text { tephra can be analysed by SEM. }\end{array}$ & $\begin{array}{l}\text { Contamination by inorganic dust; } \\
\text { difficult to identify smaller shards; } \\
\text { detailed analysis is time consuming; } \\
\text { possible contamination. }\end{array}$ & $\begin{array}{l}\text { Tephra possibly detected on } 23- \\
25 \text { and } 26-27 \text { May with most con- } \\
\text { fident identification north of } 54^{\circ} \mathrm{N} \text {. }\end{array}$ \\
\hline $\begin{array}{l}\text { Rainwater } \\
\text { (chemistry) }\end{array}$ & Public (via SEPA) & $\mathrm{n} / \mathrm{a}$ & 47 locations & $\begin{array}{l}\text { Wide coverage; existing network } \\
\text { used; easy to analyse. }\end{array}$ & $\begin{array}{l}\text { Doesn't give mass loading or con- } \\
\text { centration; mainly useful for wet } \\
\text { deposition. }\end{array}$ & $\begin{array}{l}\text { High Fe, Mn, Al concentrations in } \\
\text { N. Scotland 23-25 May; no F or pH } \\
\text { anomaly. }\end{array}$ \\
\hline Pollen slides & Met Office & $\begin{array}{l}>10 \mu \mathrm{m} \text { (smaller } \\
\text { in context) }\end{array}$ & 2 locations & $\begin{array}{l}\text { Excellent constraint on timing; wet or } \\
\text { dry deposition possible; small grains } \\
\text { identifiable in context; potentially } \\
\text { wide coverage. }\end{array}$ & $\begin{array}{l}\text { Standard petrographic methods } \\
\text { difficult on stained slides, which } \\
\text { are destroyed by further analysis; } \\
\text { network operates in summer only. }\end{array}$ & $\begin{array}{l}\text { Tephra identified on } 24-25 \text { May } \\
\text { (Eskdalemuir and Exeter) and } 27 \\
\text { May (Eskdalemuir). }\end{array}$ \\
\hline PM data & AURN, SAQD, SEPA & $<10 \mu \mathrm{m}$ & 105 locations & $\begin{array}{l}\text { Wide coverage; excellent constraint } \\
\text { on timing and near real-time results. }\end{array}$ & $\begin{array}{l}\text { High risk of contamination by } \\
\text { local sources; wet deposition not } \\
\text { detected. }\end{array}$ & $\begin{array}{l}\text { PM } 10 \text { spikes at most locations in } \\
\text { north and west UK on 23-24 May. } \\
\text { Also elevated levels on 25-26 May } \\
\text { in central Scotland. }\end{array}$ \\
\hline $\begin{array}{l}\text { Non-primary } \\
\text { PM data }\end{array}$ & AURN & $<10 \mu m$ & 45 locations & $\begin{array}{l}\text { Good coverage; reduced risk of con- } \\
\text { tamination by local sources. }\end{array}$ & $\begin{array}{l}\text { Requires simultaneous collection of } \\
\mathrm{PM}_{10}, \mathrm{PM}_{2.5}, \mathrm{NO}_{x} \text { data; currently no } \\
\text { real time analysis; wet deposition } \\
\text { not detected. }\end{array}$ & $\begin{array}{l}\text { Tephra detected moving south } \\
\text { from Aberdeen to N. England on } \\
24 \text { May. }\end{array}$ \\
\hline
\end{tabular}


The advantages and disadvantages of each method are summarised in Table 3, which includes factors such as coverage and speed of processing. Tape-on-paper samples are excellent for mapping the extent of deposition close to the visual limit and provide an additional public outreach benefit. Rainwater samples are the only method to give a quantitative loading measurement that can be compared to tephrochronology but are time-consuming to process. Rainwater chemistry can be used to map the areas of highest deposition and can be used to assess environmental impacts. In many respects, the pollen sampling network is ideal for sampling tephra as it provides good coverage, it samples all grainsizes, it works for both wet and dry deposition and it provides well-constrained timing data. Furthermore, tephra grains can be recovered from the pollen slides and subjected to SEM analysis. The strengths of air quality monitoring data are that they are already being collected in real-time and that they have wide coverage. However, further processing to identify widespread simultaneous increases in $\mathrm{PM}_{10}$ and to exclude anthropogenic sources or national/international natural pollution episodes, e.g. Saharan dust influx, are required to give confident identification of tephra plumes.

\section{Dispersal of ash from the 2011 Grímsvötn eruption}

All methods show that ash was deposited in the UK on 24. May (probably beginning overnight on 23 May) and that the highest concentrations were in Scotland (latitudes $>55^{\circ} \mathrm{N}$ ), and particularly in locations from Aberdeen northwards. This is in good agreement with air mass trajectory models, which show that the ash plume that passed over Scotland on 24 May came from the lower part of the Grímsvötn eruption column $(<4 \mathrm{~km}$ above sea level), and reinforces the finding of (Stevenson et al. 2012) that even weak eruptions or low altitude plumes can transport ash coarser than $32 \mu \mathrm{m}$ to distances of $>1000 \mathrm{~km}$. PM data show the plume moving southward across the UK, from Aberdeen to the English Midlands on 24 May. Rainwater samples and pollen slides show that small quantities of ash were also deposited in southern England. Suspended particle data from the Osiris instruments show that the majority of airborne ash in northern Scotland comprised particles $>10 \mu \mathrm{m}$ in size, and rainwater samples contained many significantly larger particles. This represents a further source of uncertainty in satellitederived estimates of the concentration of airborne ash, as the brightness temperature difference method is most sensitive to ash with a radius of $<17 \mu m$ (Wen and Rose 1994). Elevated PM levels were recorded until 26 May and rainwater and pollen data record tephra deposition at a number of sites on 26-27 May, demonstrating that ash continued to be transported to the UK as westerly winds were re-established following the initial wave of deposition. The grainsize of these particles was also smaller (3-5 $\mu \mathrm{m})$. This may reflect a longer transport path (trajectory models suggest a route beginning with initial transport towards Greenland), deposition from a weaker phase of the eruption when the plume was smaller, or deposition from a phase of the eruption that was dominated by phreatomagmatic fragmentation.

East of the UK, ash was detected in air quality monitoring data in Scandinavia (Tesche et al. 2012). TEOM instruments recorded $\mathrm{PM}_{10}$ concentrations $>40 \mu \mathrm{g} \mathrm{m}^{-3}$ in a band $57-62^{\circ} \mathrm{N}$ on $24-25$ May, including from 12:00-23:00 UTC on 24 May in Gothenburg $\left(57.71^{\circ} \mathrm{N}, 11.97^{\circ} \mathrm{E}\right)$, from 16:00-22:00 UTC on 24 May in Oslo $\left(59.91^{\circ} \mathrm{N}, 10.75^{\circ} \mathrm{E}\right)$, 20:00 UTC on 24 May to 06:00 UTC on 25 May in Stockholm $\left(59.33^{\circ} \mathrm{N}, 18.06^{\circ} \mathrm{E}\right)$ and from 05:00-14:00 UTC on 25 May in Helsinki $\left(60.17^{\circ} N, 24.94^{\circ} \mathrm{E}\right)$. Peak hourly concentrations were $167 \mu g \mathrm{~m}^{-3}$ in Gothenburg and $145 \mu \mathrm{g} \mathrm{m}^{-3}$ in Stockholm. Aerosol monitoring equipment found that the grainsize in Stockholm and Helsinki was 1-7 $\mu \mathrm{m}$ with a peak at 3-4 $\mu \mathrm{m}$ (Kerminen et al. 2011), however a number of grains 40-60 $\mu \mathrm{m}$ in length were identified in rainwater samples in Bergen, Norway $\left(60.39^{\circ} \mathrm{N}, 5.32^{\circ} \mathrm{E}\right.$; S. Pyne-O’Donell, pers. comm., 2011). Elevated sub-micron sized particle $\left(\mathrm{PM}_{1}\right)$ concentrations, dominated by aerosol of sulphate composition, were reported in Vilnius, Lithuania $\left(54.69^{\circ} \mathrm{N}\right.$, $\left.25.28^{\circ} \mathrm{E}\right), 3000 \mathrm{~km}$ from the volcano, on 24-29 May (Kvietkus et al. 2013).

The grain count and grainsize of ash deposited in the UK is similar to, or slightly lower than, that of the 2010 Eyjafjallajökull eruption (e.g. 218 grains $\mathrm{cm}^{-2}, 18 \pm 7 \mu \mathrm{m}$, in Benbecula, NW Scotland; Stevenson et al. 2012) however the Grímsvötn values represent deposition over 24 hours whereas the Eyjafjallajökull samples were exposed for variable, longer, time periods. Tephrochronologists report mass loading in peat cores as the number of ash grains in $1 \mathrm{~cm}^{3}$ of peat. The results are typically 20300 grains $\mathrm{cm}^{-3}$ (e.g. Thorarinsson 1981; Wastegård and Davies 2009) If $1 \mathrm{~cm}^{3}$ of peat is considered to represent a surface area of $1 \mathrm{~cm}^{2}$, then the grain counts per $\mathrm{cm}^{2}$ in the rainwater samples can be compared (see Table 1), and are of a similar range. There are no directly-equivalent data to convert between mass loadings reported as grain counts with mass loadings reported in $g^{-2}$. Dust deposition data collected by SEPA using "frisbee" gauges show rates of $2.06 \mathrm{~g} \mathrm{~m}^{-2} \mathrm{day}^{-1}$ in Shetland for the monitoring period from 20:00 hrs on 23 May to 18:00 on 24 May, with much lower values determined in Thurso $\left(0.08 \mathrm{~g} \mathrm{~m}^{-2} \mathrm{day}^{-1}\right)$ between $15: 20$ on 24 May and 12:15 on 26 May (SEPA 2011). The lower values at Thurso may partly reflect a longer averaging period. It is unknown how much, if any, of this material represents contamination by wind-blown dust. As with the Eyjafjallajökull eruption and tephrochronological studies, deposition was patchy 
and ash was not recovered from all locations where it may have been expected. In the case of the tape-on-paper samples, there is also the possibility that particles deposited in rainwater did not stick well to the tape. In such locations, 'swab'-type samples from smooth surfaces (e.g. car roofs) may have produced better results.

\section{Implications for health}

The results confirm that exposure to volcanic ash in the UK during the Grímsvötn eruption was minimal. Although PM concentrations were briefly raised, 24 hour mean concentrations were 'low level' according to the UK Daily Air Quality Index, suggesting that 'effects are unlikely to be noticed, even by individuals who know that they are sensitive to air pollutants' (Committee on the Medical Effects of Air Pollutants (COMEAP) 2011). The exception was Aberdeen, which was 'moderate' according to the UK Daily Air Quality Index, implying 'mild effects, unlikely to require action, may be noticed in sensitive individuals' for a short period. No adverse respiratory symptoms, such as asthma, wheeze or respiratory tract infection, attributed to the ashfall were picked up by the UK Syndromic Surveillance Network (Health Protection Agency, personal communication), as was also the case during the Eyjafjallajökull eruption (Elliot et al. 2010). Exposure was short-lived, so there was no risk of chronic disease, especially as the eruption was basaltic and therefore contained no crystalline silica, which is implicated in silicosis and lung cancer (Horwell CJ, Baxter PJ, Hillman SE, et al.: Physicochemical and respiratory toxicological profiles of the ash from the 2010 and 2011 eruptions of Eyjafjallajökull and Grímsvötn volcanoes, Iceland. Submitted to Environmental Research). Quartz grains identified by SEM-EDS analysis of rainwater and pollen samples are likely to represent wind-blown dust, as is common in the UK, and was also found during the 2010 Eyjafjallajökull eruption (Harrison and Jones 1995; Stevenson et al. 2012). It is worth noting, however, that minimal exposure to diffuse, fine volcanic ash has been associated with an increase in respiratory mortality in New Zealand, where (Newnham et al. 2010) found the highest rates of respiratory mortality of the 1990s in Auckland and Hamilton, up to $280 \mathrm{~km}$ from Ruapehu volcano, in the month following the 1996 eruption. Only traces of volcanic ash are believed to have fallen on these cities, so it is important to consider the potential human health implications for the UK following the brief period of elevated $\mathrm{PM}_{10}$, even though the distances between Iceland and the UK are far greater than those in the New Zealand case.

\section{Use of citizen science}

The tape-on-paper and rainwater chemistry samples used in this study were collected by members of the public, resulting in excellent coverage. In the case of the tapeon-paper samples, an ad hoc network was created via messages in traditional and social media. In the case of the rainwater chemistry samples, an existing network was activated. Both networks were successful, however collection generally only began on 24 May, 48 hours after the onset of the eruption. This could be improved in the event of a future eruption. Two factors contributed to the success of the tape sampling method. Firstly, the clear and simple instructions given on websites and the video ensured that the correct metadata (location, dates) were returned with each sample. Secondly, the method only required common household items and the postage to submit a paper slide was cheap, so barriers to participation were minimised.

Any use of citizen science requires an engagement with individual participants throughout the process and preferably rapid dissemination of results. This requires additional resources at times during the eruption when demands are already high. On this occasion, a letter of thanks was sent to each participant following preliminary analysis, but, because the combination of multiple datasets into final results was time consuming, it was not always possible to send personalised responses containing the results of individual sample analyses.

\section{Recommendations for future eruptions}

In 2012, the UK Government's Cabinet Office added Icelandic eruptions to the National Risk Register (Cabinet Office 2012). In the event of a Laki-type eruption, volcanic ash could reach the UK sporadically over a period of months and continual monitoring would be necessary to relate the impacts to the amount and timing of ash deposition. The number, range of data types and quality of observations of UK ash deposition from the 2011 Grímsvötn eruption were increased relative to the 2010 Eyjafjallajökull eruption (Stevenson et al. 2012), however a number of further improvements are possible prior to a future eruption. For tape-on-paper samples, a network of willing schools could be established, and the instructions can be updated to include collection of tape swabs from ash-covered surfaces such as cars (e.g. Additional file 1: Figure Sup-III). The time that the surface was last cleaned could be marked in the metadata, or it could be recorded as 'unknown'. In general, instructions to begin collecting should be passed to citizen scientists as soon as an eruption is reported. In the case of the Grímsvötn 2011 tape-on-paper samples, this may have allowed better constraint of the timing of the onset of deposition.

The rainwater network worked well to determine the locations of ash deposition and to collect grains suitable for further analysis. In order to collect larger samples, suitable for measurement of grainsize distribution by laser particle-sizer, the deposition on a large surface such as a 
roof can be measured by sampling water from the drain downpipe. This technique was used in the Faroe Islands during the 2010 Eyjafjallajökull eruption (Stevenson et al. 2012). Such data require more effort to collect but are only required from a small number of locations. In distal areas where tephra deposition is insufficient to allow sampling for tephra leachate studies, measurements of rainwater chemistry are a promising method for mapping deposition intensity and should be collected to evaluate potential effects on livestock and vegetation. By activating the pollen network outside the normal pollen season in the case of a winter eruption, and by training pollen analysts to identify tephra, it could be used to much greater effect in future eruptions.

Air quality monitoring data provide very good coverage. Adding a permanent monitoring site in northern Scotland would improve detection of volcanic ash. By calculating non-primary PM in real time during an eruption, air quality data could be used to inform modelling and health decisions. Co-located measurements of volcanic eruption tracers such as $\mathrm{SO}_{2}$ could help identification of real-time volcanic plume grounding. Finally, extending each of these networks to include volunteers and government agencies in continental Europe will help to understand tephra dispersal at even greater distances from an eruption.

\section{Conclusion}

The deposition of volcanic ash in the UK from the May 2011 Grímsvötn explosive basalt eruption was successfully mapped, along with its influence on rainwater chemistry and air quality. This study introduced new methods to constrain the temporal and geographic distribution of volcanic ash deposition at distances $>1000 \mathrm{~km}$ from a volcano, at or below the visible limit for deposition. Citizen scientists were encouraged to participate, resulting in large sample sets covering wide areas.

Tape-on-paper samples, rainwater samples, rainwater chemistry, pollen slides and air quality data all show that most deposition took place in Scotland on 2324 May, with a second, minor, period of deposition on 26-27 May. No detrimental effects on health were reported. Air mass trajectories show that this material came from the lowest $4 \mathrm{~km}$ above sea level of the eruption plume, which is consistent with observations from Iceland that most material was deposited to the south of the volcano. Rainwater samples and Osiris aerosol grainsize data show that most of the ash grains in northern Scotland were $>10 \mu \mathrm{m}$ in length, many were $>25 \mu \mathrm{m}$ and some were up to $80 \mu \mathrm{m}$ in length. These findings corroborate those from the 2010 Eyjafjallajökull eruption that even Icelandic eruptions with low plumes $(<5 \mathrm{~km}$ above sea level) can deliver volcanic ash to the UK (Stevenson et al. 2012).
The patchy distribution demonstrates that many Icelandic tephras may be missing from the tephrochronology record. Given that $85 \%$ of Icelandic eruptions are basaltic in composition and that eruptions from subglacial volcanoes e.g. Grímsvötn, Katla, are explosive (Thordarson and Larsen 2007), this suggests that the reason that only $10 \%$ of distal microtephras are basaltic has more to do with the chemical stability of shards or density-based extraction methods (e.g. Lawson et al. 2012) than it does with transport.

\section{Additional files}

Additional file 1: Supplementary figures.

Additional file 2: Supplementary materials.

Additional file 3: Detailed air quality monitoring methodology.

\section{Competing interests}

The authors declare that they have no competing interests.

\section{Authors' contributions}

JAS devised tape method and video, analysed tape, water, pollen and air quality data, compiled the different datasets and drafted manuscript. SCL organised tape and rainwater sampling and drafted parts of manuscript. AF, GWF analysed air quality data and wrote methods. AM collected and analysed rainwater samples. IWO and BJ collected data via SEPA. CJH discussed health impacts and reviewed collection methods. $\Pi$ provided proximal samples and contributed to volcanology discussion. ID analysed pollen samples and wrote methods. All authors read and approved the final manuscript.

\section{Acknowledgements}

The authors are extremely grateful to all the volunteers who collected samples and submitted them for analysis. Pollen slides from Exeter were collected by Yolanda Clewlow. Thomas Barningham checked 'blind' paper slides. David Bailey and Tony Milodowski at the British Geological Survey helped organise sample collection. Frances Beckett, Met Office, calculated air mass trajectories using the NAME model. Huw Jones and John Redshaw, as well as many field staff, from the Scottish Environment Protection Agency (SEPA) also contributed to this body of work. The AURN and SAQD air quality datasets were funded by DEFRA and the Scottish Government, respectively. John A Stevenson is funded by the Scottish Government and Marie Curie Actions via a Royal Society of Edinburgh Personal Research Fellowship. Sue Loughlin acknowledges NERC consortium grant no. NE/I015590/1 (VANAHEIM). This work is published by permission of the Executive Director, British Geological Survey (NERC). Any opinions expressed in this paper are those of the authors and are not necessarily those of their respective organisations.

\footnotetext{
Author details

${ }^{1}$ School of GeoSciences, The University of Edinburgh, Grant Institute, West Mains Road, Edinburgh, EH9 3JW, UK. ${ }^{2}$ British Geological Survey, Murchison House, West Mains Road, Edinburgh, EH9 3LA, UK. ${ }^{3}$ MRC HPA Centre for Environment and Health, King's College London, 150 Stamford Street, London SE1 9NH, UK. ${ }^{4}$ Department of Geography, University of London, Royal Holloway, Surrey, UK. ${ }^{5}$ Scottish Environment Protection Agency, Riccarton, Edinburgh, UK and School of Physical \& Geographical Sciences, Keele University, Keele, Staffordshire, ST5 5BG, UK. ${ }^{6}$ Scottish Environment Protection Agency, Riccarton, Edinburgh, UK. ${ }^{7}$ Department of Earth Sciences, Durham University, Durham, DH1 3LE, UK. ${ }^{8}$ Met Office, Eskdalemuir, Dumfries and Galloway, DG13 0QW, UK. ${ }^{9}$ Faculty of Earth Sciences, University of Iceland, Sturlugata 7, Reykjavik IS101, Iceland.
}

Received: 16 November 2012 Accepted: 26 April 2013 Published: 24 May 2013 


\section{References}

Airborne Particles Expert Group (APEG) (1999) Source apportionment of particulate matter in the United Kingdom. Tech Rep. HMSO

Ayris PM, Delmelle P (2012) The immediate environmental effects of tephra emission. Bull Volcanology 74(9): 1905-1936. doi:10.1007/s00445-012-0654-5

Bellomo S, D'Alessandro W, Longo M (2003) Volcanogenic fluorine in rainwater around active degassing volcanoes: Mt. Etna and Stromboli Island, Italy. Sci Total Environ 301(1-3): 175-185. doi:10.1016/S0048-9697(02)00284-X

Cabinet Office (2012) National Risk Register for Civil Emergencies. Tech. Rep. 408697 / 0212, London

Committee on the Medical Effects of Air Pollutants (COMEAP) (2011) Review of the UK Air Quality Index. COMEAP

Cronin S, Hedley M, Neall V, Smith R (1998) Agronomic impact of tephra fallout from the 1995 and 1996 Ruapehu Volcano eruptions New Zealand. Environ Geology 34(1): 21-30

Elliot AJ, Singh N, Loveridge P, Harcourt S, Smith S, Pnaiser R, Kavanagh K, Robertson C, Ramsay CN, McMenamin J, Kibble A, Murray V, Ibbotson S, Catchpole M, McCloskey B, Smith GE (2010) Syndromic surveillance to assess the potential public health impact of the Icelandic volcanic ash plume across the United Kingdom, April 2010. Euro Surveillance: Bulletin Europen Sur Les Maladies Transmissibles = European Communicable Disease Bulletin 15(23). PMID:20546694

Fuller GW, Green D (2004) The impact of local fugitive from building works and road works on the assessment of the European Union Limit Value. Atmos Environ 38(30): 4993-5002. doi:10.1016/j.atmosenv.2004.06.024

Fuller, G W, Green D (2006) Evidence for increasing concentrations of primary PM10 in London. Atmos Environ 40(32): 6134-6145. doi:10.1016/S1352-2310(01)00580-5

Fuller GW, Carlsaw D, Lodge H (2002) An empirical approach for the prediction of daily mean PM10 concentrations. Atmos Environ 36(9): 1431-1441. doi:10.1016/j.atmosenv.2006.05.031

Grattan J (2005) Pollution and paradigms: lessons from Icelandic volcanism for continental flood basalt studies. Lithos 79(3-4): 343-353. doi:10.1016/j.lithos.2004.09.006

Great Britain - Standing, Committee of Analysts (1978) Methods for the Examination of Waters and Associated Materials: The measurement of electrical conductivity and the laboratory determination of the $\mathrm{pH}$ value of natural, treated and waste waters. No. 14 in Blue book, H.M.S.O, London

Green DC, Fuller GW, Baker T (2009) Development and validation of the volatile correction model for PM10 - An empirical method for adjusting TEOM measurements for their loss of volatile particulate matter. Atmos Environ 43(13): 2132-2141. doi:10.1016/j.atmosenv.2009.01.024

Gudmundsson MT, Höskuldsson ÁČ, Larsen G, Thordarson T, Óladóttir B, Oddsson B, Gudnason J, Högnadóttir T, Stevenson JA, Houghton B, McGarvie DW, Sigurdardottir G (2012) Geophysical Research Abstracts, pp EGU2012-EGU12,119

Harrison D, Maggs R, Booker J (2008) UK Equivalence Programme for Monitoring of Particulate Matter. Tech Rep BV/AQ/AD202209/DH/2396. Bureau Veritas, London

Harrison RM, Jones M (1995) The chemical composition of airborne particles in the UK atmosphere. Sci Total Environ 168(3): 195-214

International Organisation for Standardisation (ISO) (1995) Guide to the expression of uncertainty in measurement. Tech. rep. Geneva

Jones MT, Gislason SR (2008) Rapid releases of metal salts and nutrients following the deposition of volcanic ash into aqueous environments. Geochimica et Cosmochimica Acta 72(15): 3661-3680. doi:10.1016/j.gca.2008.05.030

Jude-Eton T, Thordarson T, Gudmundsson M, Oddsson B (2012) Dynamics, stratigraphy and proximal dispersal of supraglacial tephra during the ice-confined 2004 eruption at Gr'imsvötn Volcano, Iceland. Bull Volcanology: 1-26. doi:10.1007/s00445-012-0583-3

Kerminen VM, Niemi JV, Timonen H, Aurela M, Frey A, Carbone S, Saarikoski S, Teinilä K, Hakkarainen J, Tamminen J, Vira J, Prank M, Sofiev M, Hillamo R (2011) Characterization of a volcanic ash episode in southern Finland caused by the Grimsvötn eruption in Iceland in May 2011. Atmos Chem Phys 23: 12,227-12,239. doi:10.5194/acp-11-12227-2011

Kvietkus K, Sakalys J, Didzbalis J, Garbariene I, Spirkauskaite N, Remeikis V (2013) Atmospheric aerosol episodes over Lithuania after the May 2011 volcano eruption at Grimsvötn, Iceland. Atmos Res 122: 93-101. doi:10.1016/j.atmosres.2012.10.014
Käpylä M, Penttinen A (1981) An evaluation of the microscopical counting methods of the tape in Hirst-Burkard pollen and spore trap. Grana 20(2): 131-141. doi:10.1080/00173138109427653

Lawson IT, Swindles GT, Plunkett G, Greenberg D (2012) The spatial distribution of Holocene cryptotephras in north-west Europe since $7 \mathrm{ka}$ : implications for understanding ash fall events from Icelandic eruptions. Quaternary Sci Rev 41: 57-66. doi:10.1016/j.quascirev.2012.02.018

Leadbetter SJ, Hort MC (2011) Volcanic ash hazard climatology for an eruption of Hekla Volcano, Iceland. J Volcanology Geothermal Res 199(3-4): 230-241. doi:10.1016/j.jvolgeores.2010.11.016

Newnham RM, Dirks KN, Samaranayake D (2010) An investigation into longdistance health impacts of the 1996 eruption of Mt Ruapehu, New Zealand. Atmos Environ 44(12): 1568-1578. doi:10.1016/j.atmosenv.2009.12.040

Petersen GN, Bjornsson H, Arason P (2012a) The impact of the atmosphere on the Eyjafjallajökull 2010 eruption plume. J Geophysical Res 117: 14. doi:10.1029/2011JS01672

Petersen GN, Bjornsson H, Arason P, von Löwis S (2012b) Two weather radar time series of the altitude of the volcanic plume during the May 2011 eruption of Gr'imsvötn, Iceland. Earth Syst Sci Data 4(1): 121-127. doi:10.5194/essd-4-121-2012

Scottish Environment, Protection Agency (SEPA) (2011) Gr'imsvötn volcano (Iceland) eruption May 2011: assessing the potential consequences of ash deposition in Scotland. Tech. rep. Edinburgh. Retrieved from http://www. sepa.org.uk/about_us/news/other/grimsvotn_volcanic_eruption.aspx

Sigmarsson O (2012) Mafic intrusions triggering eruptions in Iceland. Geophy 14: EGU2012-12,722

Stevenson JA, Loughlin S, Rae C, Thordarson T, Milodowski AE, Gilbert JS, Harangi S, Lukács R, Højgaard B, Árting U, Pyne-O'Donnell S, MacLeod A, Whitney B, Cassidy M (2012) Distal deposition of tephra from the Eyjafjallajökull 2010 summit eruption. J Geophysical Res 117: 10. doi:10.1029/2011JB008904

Swindles GT, Lawson IT, Savov IP, Connor CB, Plunkett G (2011) A 7000 yr perspective on volcanic ash clouds affecting northern Europe. Geology 39(9): 887-890. doi:10.1130/G32146.1

Tesche M, Glantz P, Johansson C, Norman M, Hiebsch A, Ansmann A, Althausen D, Engelmann R, Seifert P (2012) Volcanic ash over Scandinavia originating from the Grimsvotn eruptions in May 2011. J Geophysical Res-Atmospheres 117. doi:10.1029/2011JD017090

Thorarinsson S (1981) Greetings from Iceland: ash-falls and volcanic aerosols in Scandinavia. Geografiska Annaler, Ser A 63(3-4): 109-118

Thordarson T, Larsen G (2007) Volcanism in Iceland in historical time: Volcano types, eruption styles and eruptive history. J Geodynamics 43(1): 118-152. doi:10.1016/j.jog.2006.09.005

Van Osdell DW (1991) Test of the Rupprecht and Patashnick TEOM PM10 sampler inlet at 2 and $24 \mathrm{~km} / \mathrm{h}$. Wind Tunnel Test Report 29A, Research Triangle Institute, North Carolina: 21

Wastegård S, Davies SM (2009) An overview of distal tephrochronology in northern Europe during the last 1000 years. J Quaternary Sci 24(5): 500-512. doi:10.1002/jgs.1269

Wen S, Rose WI (1994) Retrieval of sizes and total masses of particles in volcanic clouds using AVHRR bands 4 and 5. J Geophysical Res 99(D3): 5421-5431. doi:10.1029/93JD03340

White J, Houghton B (2006) Primary volcaniclastic rocks. Geology 34(8): 677-680. doi:10.1130/G22346.1

Wilson TM, Stewart C, Sword-Daniels V, Leonard GS, Johnston DM, Cole JW, Wardman J, Wilson G, Barnard ST (2012) Volcanic ash impacts on critical infrastructure. Phys Chem Earth, Parts A/B/C 45-46: 5-23. doi:10.1016/j.pce.2011.06.006

Wilson W, Chow J, Claiborn C, Fusheng W, Engelbrecht J, Watson JG (2002) Monitoring of particulate matter outdoors. Chemosphere 49: 1009-1043

Witham C, Hort M, Potts R, Servranckx R, Husson P, Bonnardot F (2007) Comparison of VAAC atmospheric dispersion models using the 1 November 2004 Grimsvötn eruption. Meteorological Appl 14(1): 27-38

\section{doi:10.1186/2191-5040-2-3}

Cite this article as: Stevenson et al:: UK monitoring and deposition of tephra from the May 2011 eruption of Grímsvötn, Iceland. Journal of Applied Volcanology 2013 2:3. 